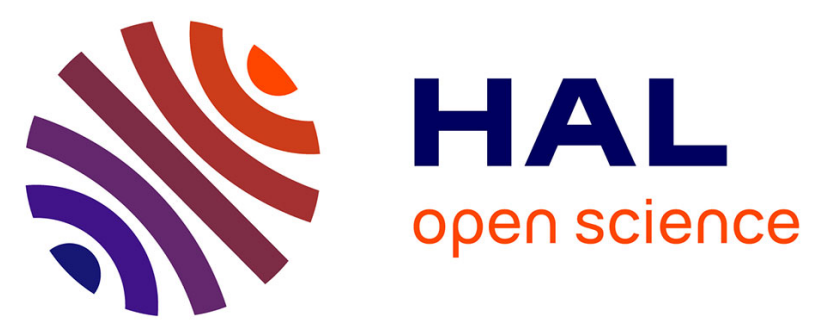

\title{
The geological signature of a slab tear below the Aegean
}

Laurent Jolivet, Armel Menant, Pietro Sternai, Aurélien Rabillard, Laurent

Arbaret, Romain Augier, Valentin Laurent, Alexandre Beaudoin, Bernhard

Grasemann, Benjamin Huet, et al.

\section{- To cite this version:}

Laurent Jolivet, Armel Menant, Pietro Sternai, Aurélien Rabillard, Laurent Arbaret, et al.. The geological signature of a slab tear below the Aegean. Tectonophysics, 2015, 659, pp.166-182. 10.1016/j.tecto.2015.08.004 . insu-01187096

\section{HAL Id: insu-01187096 \\ https://hal-insu.archives-ouvertes.fr/insu-01187096}

Submitted on 26 Aug 2015

HAL is a multi-disciplinary open access archive for the deposit and dissemination of scientific research documents, whether they are published or not. The documents may come from teaching and research institutions in France or abroad, or from public or private research centers.
L'archive ouverte pluridisciplinaire $\mathbf{H A L}$, est destinée au dépôt et à la diffusion de documents scientifiques de niveau recherche, publiés ou non, émanant des établissements d'enseignement et de recherche français ou étrangers, des laboratoires publics ou privés.

\section{(ㅇ)(1) $\$$}

Distributed under a Creative Commons Attribution - NonCommercial - NoDerivatives| 4.0 


\section{Accepted Manuscript}

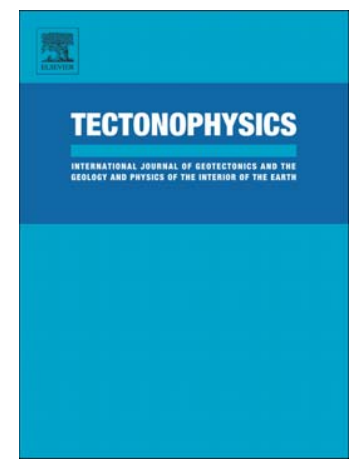

The geological signature of a slab tear below the Aegean

Laurent Jolivet, Armel Menant, Pietro Sternai, Aurélien Rabillard, Laurent Arbaret, Romain Augier, Valentin Laurent, Alexandre Beaudoin, Bernhard Grasemann, Benjamin Huet, Loïc Labrousse, Laetitia Le Pourhiet

PII: S0040-1951(15)00422-9

DOI: doi: $10.1016 /$ j.tecto.2015.08.004

Reference: $\quad$ TECTO 126724

To appear in: $\quad$ Tectonophysics

Received date: 27 November 2014

Revised date: $\quad 4$ August 2015

Accepted date: 6 August 2015

Please cite this article as: Jolivet, Laurent, Menant, Armel, Sternai, Pietro, Rabillard, Aurélien, Arbaret, Laurent, Augier, Romain, Laurent, Valentin, Beaudoin, Alexandre, Grasemann, Bernhard, Huet, Benjamin, Labrousse, Loïc, Le Pourhiet, Laetitia, The geological signature of a slab tear below the Aegean, Tectonophysics (2015), doi: 10.1016/j.tecto.2015.08.004

This is a PDF file of an unedited manuscript that has been accepted for publication. As a service to our customers we are providing this early version of the manuscript. The manuscript will undergo copyediting, typesetting, and review of the resulting proof before it is published in its final form. Please note that during the production process errors may be discovered which could affect the content, and all legal disclaimers that apply to the journal pertain. 


\section{The geological signature of a slab tear below the Aegean}

Laurent Jolivet ${ }^{1,2,3}$, Armel Menant ${ }^{1,2,3}$, Pietro Sternai ${ }^{1,2,3,4}$, Aurélien Rabillard ${ }^{1,2,3}$, Laurent Arbaret $^{1,2,3}$, Romain Augier ${ }^{1,2,3}$, Valentin Laurent ${ }^{1,2,3}$, Alexandre Beaudoin ${ }^{1,2,3}$, Bernhard Grasemann ${ }^{5}$, Benjamin Huet ${ }^{5}$, Loïc Labrousse ${ }^{6}$ and Laetitia Le Pourhiet ${ }^{6}$

(1) Univ d'Orléans, ISTO, UMR 7327, 45071, Orléans, France

(2) CNRS/INSU, ISTO, UMR 7327, 45071 Orléans, France

(3) BRGM, ISTO, UMR 7327, BP 36009, 45060 Orléans, France

(4) Tectonic Observatory, California Institute of Technology, Pasadena, CA 90125, United States

(5) Structural Processes Group Vienna, University of Vienna, A-1090 Vienna, Austria

(6) ISTEP, UPMC-CNRS, UMR 7193, 4 Place Jussieu, 75252 Paris cedex 05, France

\section{Keywords:}

Backarc extension, slab tear, metamorphic core complexes, detachments, Aegean, Mediterranean

\section{Highlights}

- Rotation of Hellenides is coeval with granite migration

- Migration of granitoids signs a slab tear in the Cyclades

- HT domes and a left-lateral gradient of extension also sign the tear

\section{Abstract}

In this paper we explore the geology of the Aegean region in the Miocene to identify the geological signature of a first-order slab tear observed in all tomographic models. From 15 to $8 \mathrm{Ma}$, the tear is associated, spatially and timely, with a fast clockwise rotation of the External Hellenides, alkaline volcanism, high-temperature metamorphic domes with a predominance of north-dipping detachments, south-westward migration of granitoids intrusions. These features suggest a warmer geodynamic environment during the rotation and the impact of a hot mantle flow associated with the tear. The $\sim 8 \mathrm{Ma}$ duration between the first hightemperature metamorphic domes in the centre of the archipelago and the beginning of the fast rotation may correspond to the time needed for the slab to bend, stretch and finally tear. 


\section{1- Introduction}

Tearing of subducting slabs play a major role in lithospheric-scale models of the Mediterranean region (Carminati et al., 1998; Wortel and Spakman, 2000; Piromallo and Morelli, 2003; Faccenna et al., 2004; Spakman and Wortel, 2004; Faccenna et al., 2005; Govers and Wortel, 2005; Jolivet et al., 2009; 2013). Similarly to slab break-off (i.e., detachment of the hanging oceanic slab by a sub-horizontal rupture), slab tearing (i.e., subvertical ruptures within the subducting slab) in the Mediterranean is deduced from seismic tomography models of the mantle and often associated with specific magmatic signature at the surface (Faccenna et al., 2007; Dilek and Altunkaynak, 2009). Govers and Wortel (2005) have proposed to name such lateral tears STEP-faults, standing for Subduction-Transform Edge Propagator and they studied them through mechanical modelling. They concluded that such STEPs can be stable plate tectonic features and thus influence the kinematics around for significant periods of time. However, the influence of tearing the subducting slab on the tectonic evolution of the subduction upper plate is still poorly known.

Numerical or analogue models show that laterally unconfined slabs and tears in subducting slabs should induce complex 3D mantle flow with significant toroidal component around the edges of torn slabs (Funiciello et al., 2003; 2006; Piromallo et al., 2006; Faccenda and Capitanio, 2012; Moresi et al., 2014; Sternai et al., 2014), which seems to be reflected in some seismic anisotropy data sets (Lin et al., 2011). In the case of the Aegean, the flow pattern suggested by the SKS anisotropy appears quite simple except for some anomalous directions that may result from a slab tear below Western Turkey (Paul et al., 2014). The presence of adakitic magmatic products is for instance a common characteristic leading to infer the presence of a slab tear or detachment (Yogodzinski et al., 2001; Omrani et al., 2008; Réhault et al., 2012). This common inference is based upon the simple idea that an anomalously hot mantle is required to produce this type of magma. The rise of the asthenospheric mantle through a tear may very well provide this thermal anomaly, but the geological effects of such tears are not clear and they are likely to be highly variable depending upon the area considered. Using the wealth of geological and geophysical data accumulated in the Mediterranean region we address in this work the possible geological signature of a slab tear below the Aegean region.

The geodynamic evolution of the Mediterranean region is largely controlled by the behaviour of the African slab in the asthenosphere (Doglioni et al., 2002; Faccenna et al., 2007; Jolivet et al., 2009; Faccenna and Becker, 2010). The apparent geometrical complexity 
of arcuate mountain belts (Alps, Carpathians, Dinarides, Hellenides) and back-arc basins (e.g. Alboran Sea, Liguro-Provençal Basin, Tyrrhenian Sea, Aegean Sea, Pannonian Basin) results from slab backward migration and their tearing or break-off (Wortel and Spakman, 2000; Faccenna et al., 2004; Papanikolaou and Royden, 2007; Royden and Papanikolaou, 2011; Berk Biryol et al., 2011; van Hinsbergen and Schmid, 2012; Jolivet et al., 2013; Guillaume et al., 2013; Gessner et al., 2013; Schildgen et al., 2014). The progressive tearing of the Tyrrhenian slab has resulted in the present steeply-dipping narrow stripe of lithosphere seen in tomographic models and in a progressive acceleration of slab retreat with time (Carminati et al., 1998; Faccenna et al., 2004; Rosenbaum and Lister, 2004; Faccenna et al., 2007). Several studies have described the geodynamic evolution of sedimentary basins and magmatism in this region during slab retreat and progressive tearing (van der Meulen et al., 1998; Faccenna et al., 2007; Massari and Prosser, 2013). Similar contexts can be found in the Alboran region or in the Aegean but, so far, very few studies were conducted to see which type of crustal structures could be diagnostic of slab tearing at depth, except for the work of Gessner et al. (2013) who have interpreted the exhumation and extension of the Menderes Massif as a consequence of a slab tear below Western Anatolia and the formation of a leftlateral transtensional shear zone, which they name the West Anatolia Transfer Zone. In a numerical study, Le Pourhiet et al. (2012) have furthermore proposed that metamorphic domes elongated parallel to the direction of stretching in the Aegean (a-type domes, Jolivet $e t$ $a l ., 2004)$ could be formed in such environments by differential stretching above a slab tear. The model concerns the formation of domes in a transtensional strike-slip regime but the tear itself is not modelled. In a more recent study, Sternai et al. (2014) model the distribution of strain in the upper plate above a slab tear but the detailed kinematics of exhumed material above the tear is not modelled either. By mean of analogue modelling Guillaume et al. (2013) have explored the effect of lateral variations in the nature of the subducting plate (oceanic $v s$ continental) and they suggested that the western recent tear of the Aegean slab is responsible for the dextral shearing of the upper plate and formation of the Central Hellenic Shear Zone described by Royden and Papanikolaou (2011).

Figure 1: Geological and geodynamic context of exhumed metamorphic complexes in the Aegean Sea and Anatolia and (insert) P-wave seismic tomography model of the upper mantle (average between 100 and $250 \mathrm{~km}$ ) after Piromallo and Morelli (2003). The geometry of the slab tear is shown with the interpretation of the P-wave tomographic 
model of Berk Biryol et al (2011) and the isobaths of the slab shown in Gessner et al. (2013).

In this paper, we explore the geology of the Aegean Sea (Figure 1) in the Miocene with the aim of searching for crustal structures and magmatic events that could be related to a firstorder slab tear seen in all tomographic models below the eastern Aegean (de Boorder et al., 1998; Piromallo and Morelli, 2003; Dilek and Altunkaynak, 2009; Berk Biryol et al., 2011; Salaün et al., 2012; Ersoy and Palmer, 2013; Jolivet et al., 2013). We confirm that the tear, associated with a long-recognized fast clockwise rotation of the external Hellenides from 15 to $8 \mathrm{Ma}$ (Kissel and Laj, 1988; van Hinsbergen et al., 2005b), is also spatially and timely associated with alkaline volcanism, the formation of high-temperature and metamorphic domes with axes parallel to the direction of extension and a predominance of top-to-the north shearing deformation and north-dipping detachments and with the southwestward migration of granitoids intrusions.

Figure 2: Synthesis of the main tectonic and magmatic events in the Aegean region (references in text and in Jolivet and Brun, 2010).

\section{2- Geological context}

Temporal constraints on the geological evolution of the Aegean Sea and the Cyclades are compiled in figures 2 and 3, respectively.

Figure 3: timing of metamorphic and exhumation events as well as the history of plutons from intrusion to final cooling in the Aegean region, from (Altherr et al., 1982; Henjes-Kunst et al., 1988; Wijbrans and McDougall, 1988; Schliestedt et al., 1994; Keay et al., 2001; Hejl et al., 2002; Parra et al., 2002; Ring et al., 2003; Bröcker et al., 2004; Jolivet et al., 2004a; Kumerics et al., 2005; Brichau et al., 2006; Bröcker and Franz, 2006; Duchêne et al., 2006; Martin et al., 2006; Brichau et al., 2007; 2008; Skarpelis et al., 2008; Baltatzis et al., 2009; Iglseder et al., 2009; Liati et al., 2009; Seward et al., 2009; Bolhar et al., 2010; Brichau et al., 2010; Jolivet et al., 2010; Denèle et al., 2011; Ring et al., 2011; Schneider et al., 2011; Grasemann et al., 2012; Bargnesi et al., 2013; Berger et al., 2013; Bröcker et al., 2013; Soukis and Stockli, 2013; Beaudoin et al., 2014; Huet et al., 2014; Laurent et al., 2015) 
The Aegean Sea (Figs 1, 2) started to form in the Early Oligocene as a consequence of the retreat of the African slab subducting below the southern margin of Eurasia (Jolivet and Faccenna, 2000; Jolivet and Brun, 2010). Back arc extension then affected the crust previously thickened by the formation of the Hellenides in the west and the Taurides in the east by subduction and collision of the Apulian microcontinent with Eurasia (Bonneau and Kienast, 1982; Dercourt et al., 1986; van Hinsbergen et al., 2005a). After a first Late Jurassic obduction, best recorded in the Internal Hellenides (Aubouin et al., 1962; Jacobshagen et al., 1978; Ross and Zimmerman, 1996), and a second Late Cretaceous obduction along the IzmirAnkara suture zone (Brunn et al., 1976; Sengör and Yilmaz, 1981; Okay and Tüysüz, 1999), the entrance of the Apulian crust in the subduction zone led to an episode of crustal thickening and formation-exhumation of high-pressure and low-temperature metamorphic units like the Cycladic Blueschists, from the Paleocene to the Eocene (Figs. 2 and 4) (Blake et al., 1981; Bonneau and Kienast, 1982; Jolivet et al., 2003; Brun and Faccenna, 2008; Jolivet and Brun, 2010; Ring et al., 2010).

The age of the Aegean extension is actually debated. If one considers the Eocene extension of the Rhodope as a part of the history of the Aegean Sea it then started earlier than $35 \mathrm{Ma}$; extension in the Rhodope indeed started as soon as the Eocene and marine sediments were deposited during this period (Brun and Sokoutis, 2010). According to Ring et al. (2010) extension started only some $23 \mathrm{Ma}$, which corresponds to the age of the earliest sediments found in the Aegean islands. We consider that the Eocene period of extension, that is coeval with the subduction of the Cycladic Blueschists (Brun and Faccenna, 2008; Jolivet and Brun, 2010), does not correspond to the same event of retreat because the magmatic arc was not moving during this period. It started its fast southward movement only at $35 \mathrm{Ma}$ (Jolivet and Brun, 2010).

Figure 4: Granitoids in the Aegean region in their tectonic framework

From the Oligocene onward, during southward slab rollback, the internal zones of the Hellenides were subjected to back-arc late-orogenic extension, while the frontal zones were still under compression in Crete and the Peloponnese, where nappe stacking and HP-LT metamorphism were still active. This tectonic evolution results from the continuous subduction of the single African lithosphere and accretion of crustal units (Jolivet et al., 2003; 
van Hinsbergen et al., 2005a; Jolivet and Brun, 2010). Since the Late Cretaceous, some 1500 $\mathrm{km}$ of lithospheric mantle were consumed in the Hellenic subduction zone, which approximately corresponds to the length of the high velocity anomaly seen in tomographic models (de Boorder et al., 1998; Wortel and Spakman, 2000; Faccenna et al., 2003; Piromallo and Morelli, 2003; van Hinsbergen et al., 2005a; Jolivet and Brun, 2010; Berk Biryol et al., 2011; Salaün et al., 2012).

All available tomographic models show in addition a major discontinuity in the distribution of high velocity anomalies below the eastern Aegean (figure 1, inset), which is interpreted as a slab tear (de Boorder et al., 1998; Piromallo and Morelli, 2003; Berk Biryol et al., 2011; Salaün et al., 2012). The exact geometry of the tear is unknown. It depends upon the method used to image the slab at depth but its existence is not debated. By "tear" we mean here a vertical discontinuity in the slab whatever the mechanism that produced it initially. Whether it started from the beginning as a vertical "fault" like in Govers and Wortel (2005) or it was first a horizontal rupture that then propagated upward is impossible to assess with the available data set. It remains that one observe a large latitudinal offset between the narrow slab resting below Anatolia and the Hellenic slab below the Aegean. We call this offset a tear. One of the best images of the tear is provided by the P-wave tomographic model of Berk Biryol et al. (2011), and its interpretation in Gessner et al. (2013) (figure 1). Although less spectacular and probably more recent, a second tear has been recognized more recently below the western Aegean (Suckale et al., 2009; Gesret et al., 2011; Royden and Papanikolaou, 2011; Vassilakis et al., 2011).

The present-day surface velocity field deduced from GPS data shows the westward displacement of the rigid Anatolian block, rotation about a pole located north of Egypt, and an additional non-rigid component involving faster southward motion of the Aegean region and extension in Western Turkey and the Corinth Rift region (McClusky et al., 2000; Reilinger et al., 2010). This westward motion of Anatolia is a consequence of (1) slab retreat and slab tearing (Faccenna et al. 2006; Sternai et al., 2014) and (2) Arabia-Eurasia collision (extrusion) (Armijo et al., 1999). In more details, the GPS velocity field reveals two toroidal cells, one counterclockwise in the east and one clockwise in the west (Pérouse et al., 2012). Recent clockwise palaeomagnetic rotations are recorded within the Central Hellenic Shear Zone that encompasses a series of NW-SE trending grabens from the Gulf of Evia to the Peloponnese (Royden and Papanikolaou, 2011; Bradley et al., 2013). On the long term, N-S to NE-SW extension has moved the Hellenic Arc several hundreds of kilometres toward the south during back-arc extension since the Oligocene and this was accompanied by fast clockwise rotation 
of the external Hellenides during the outward migration of the thrust front between $\sim 15$ and 8 Ma, as revealed by paleomagnetic data (Kissel and Laj, 1988; van Hinsbergen et al., 2005b). The rotation pattern is more complex in the internal zones and the Aegean with some islands showing either clockwise or counterclockwise rotations (Kissel and Laj, 1988; Morris and Anderson, 1996). In the Menderes Massif, a contemporary counterclockwise rotation occurred between 16 and $6 \mathrm{Ma}$ about a close-by pole leading to the opening of the main grabens (van Hinsbergen, 2010).

Figure 5: Tectonic map of the Cyclades archipelago showing the main metamorphic core complexes and plutons, as well as kinematic indicators. After Gautier and Brun (1994a, b), Huet et al. (2009); Jolivet et al., (2010; 2013), Grasemann et al. (2012), Augier et al. (submitted). NCDS: North Cycladic Detachment System. WCDS: West Cycladic Detachment System.

In response to slab retreat, several Metamorphic Core Complexes (MCC) have been exhumed during the Oligocene and Miocene from north to south (Figures 2, 4 and 5): the Rhodope massif and its equivalent in Turkey, the Kazdag massif [Okay and Satir, 2000; Bonev and Beccaletto, 2007; Bonev et al., 2009; Cavazza et al., 2009], the Menderes massif and the Cyclades. The Rhodope massif started its exhumation in the Eocene and completed it during the formation of the Aegean Sea in the Oligocene and Miocene (Moriceau, 2000; Bonev et al., 2006; Brun and Sokoutis, 2007; Burg, 2011). At this time, the Cyclades and the northern part of the Menderes massif were mainly exhumed respectively below the North Cycladic Detachment System (NCDS) and its possible lateral extension, the Simav Detachment (Ring et al., 1999a; Bozkurt and Oberhänsli, 2001; Gessner et al., 2001; Isık et al., 2003; van Hinsbergen, 2010; Bozkurt et al., 2011a; 2011b; Jolivet et al., 2013). The transition between the NCDS and the Simav Detachment in the eastern Cyclades has been interpreted as a left lateral transfer zone (Ring et al., 1999b; Jolivet et al., 2013; Gessner et al., 2013).

More precisely, the middle and deep crusts in the Cyclades were exhumed below a few major detachments (Figs. 4, 5). Extension along the north-dipping NCDS (Jolivet et al., 2010) and the south-dipping West Cycladic Detachment System (WCDS) (Grasemann et al., 2012) has led to the exhumation of the northern and western Cyclades, respectively. The exhumation of the central Cyclades was achieved below a north-dipping detachment in Naxos and Paros (Urai et al., 1990; Buick, 1991; Gautier et al., 1993). The geometrical relations of this detachment with the NCDS, whether they correspond to a single structure or not, is still 
debated (Philippon et al., 2012; Jolivet et al., 2013). The direction of extension is quite constantly N-S or NE-SW over a large region that encompasses the Cyclades, the Rhodope and the Menderes as shown by maps of stretching lineations (Jolivet et al., 2013). The distribution of kinematic indicators associated with those detachments shows a more symmetrical pattern in the west where the WCDS and the NCDS bound a series of metamorphic core complexes (MCC), than in the centre of the archipelago where top-to-the north shear sense are recorded all the way to the south, until the islands of Folegandros and Sikinos (Augier et al., 2014). Although some authors suggested the existence of a South Cyclades Shear Zone (Lister et al., 1984; Ring et al., 2011), Huet et al. (2009) have shown that this shear zone was active under HP-LT conditions and is unrelated to the Miocene extension.

The exhumation of the Cycladic MCCs was achieved in two steps (Jolivet et al., 2004a) (figs 3, 5, 6): the first step (from 30-35 Ma to 15-17 Ma) saw the formation of "cold" domes where HP-LT Eocene parageneses are more or less well preserved (Andros, Tinos, Kea, Kythnos), while the second step (from 20 to $8 \mathrm{Ma}$ ) is characterized by the final exhumation of "hot" domes where greenschist facies to amphibolite-facies rocks and migmatites predominate. Some of the domes are elongated perpendicular to the stretching lineation (Andros, Tinos ; "b-type" domes, Jolivet et al., 2004), other are parallel to the stretching lineation ("a-type" domes, Naxos, Mykonos, Kea, Kythnos). In the eastern part of the Aegean Sea, the Ikaria metamorphic dome is also characterized by a high-temperature and lowpressure regime (Beaudoin et al., 2014; Laurent et al., 2015). The domal shape of Aegean MCCs may result from different processes. The northern Cyclades show dome axes oriented parallel to the alignment of islands WNW-ESE. This component of doming can be a consequence of extension, either crustal-scale sigmoids or boudins associated with the main detachment, the NCDS (Jolivet et al., 2004a; 2010). But most of these MCCs show in addition large-scale folds oriented N-S to NE-SW (Avigad et al., 2001) and the clearest evidence is found in the centre of the Cyclades in Naxos and Paros islands. The northern Cyclades (Andros, Tinos, Mykonos) and the south-western Cyclades (Kea, Kythnos, Serifos) also show such large-scale folds with similar orientations with smaller amplitude. These later folds may sign a component of perpendicular shortening during extension (Angelier, 1976; Ring et al., 1999; Avigad et al., 2001; Menant et al., 2013). The relations of these folds to extension are not entirely clear. Part of the folding is clearly late with respect to the formation of the brittle detachments as these are folded like on Mykonos or Naxos (Gautier et al., 1993; Lecomte et al. 2010). On the other hand, the large-scale folds are associated with smaller- 
scale folds with parallel axes formed in high-temperature ductile conditions like in the core of the Naxos dome associated by Vanderhaeghe (2004) to a component of diapirism during the emplacement of the dome. The folds thus seem partly contemporaneous and partly younger than extension. They have been explained either by a simple constrictional component during extension (Gautier et al., 1999) or by an E-W shortening component due to the escape of Anatolia (Menant et al., 2013; Philippon et al., 2014).

Figure 6: Three sections through the Cyclades metamorphic core complexes.

From $\sim 35 \mathrm{Ma}$ to the Present, the magmatic arc has progressively migrated southward following slab retreat (Fytikas et al., 1984; Jolivet et al., 2004a; Pe-Piper and Piper, 2006, 2007). A N-S transect across the central Aegean all the way to the Rhodope shows at first order this southward migration of magmatic products with time (Jolivet and Brun, 2010; Jolivet et al., 2013). However, the picture is more complex when looking laterally and the nature of magmatism changes through time (Pe-Piper and Piper, 2006, 2007; Ersoy and Palmer, 2013). Two important observations can be made at this stage: (1) a surge of alkaline and shoshonitic volcanism is recorded from $\sim 17 \mathrm{Ma}$ in the eastern Cyclades and western Anatolia, which has been attributed by several authors (Dilek and Altunkaynak, 2009; Seghedi et al., 2013) to the eastern Aegean slab tear and (2) granitoids intruded the Aegean MCCs during a rather short period between $\sim 17 \mathrm{Ma}$ and $8 \mathrm{Ma}$, which approximately covers the same period as the formation of high-temperature a-type domes and the fast rotation of the external Hellenides.

This short review of the geological context of the Aegean domain shows that the 17-8 Ma period seems to be a turning point, with significant changes in the style of extension and magmatism contemporaneously with the rigid rotation of the subduction front to the west. In the following, we precise the evolution of the domes and their relations to granitoid intrusions (see figure 3 and references therein for timing).

\section{3- Low-temperature metamorphic core complexes}

3-1 Syros and Sifnos. Among metamorphic units, the well-preserved Cycladic Blueschists of Syros and Sifnos islands were mostly exhumed early in the history of the 
Aegean region, and most of the exhumation took place in the Eocene (see fig. 3 for references). Only the final brittle exhumation was achieved in the Oligocene and Miocene. The main structure that accommodated exhumation is the Vari Detachment that crops out on the islands of Syros and Tinos. The deepest parts of the metamorphic pile of Syros and Sifnos display younger ages for the ductile exhumation (see Bröcker et al., 2013). The kinematics of the main exhumation below the Vari detachment is mostly top-to-the east (Trotet et al., 2001a; 2001b) and it precedes the Aegean extension.

3-2 Andros and Tinos. Andros and Tinos islands show two large domes of foliation, elongated perpendicular to the stretching lineation that trends NE. The two domes were exhumed below the North Cycladic Detachment System in the Oligocene and Miocene (Gautier and Brun, 1994a; Jolivet and Patriat, 1999; Jolivet et al., 2004a; 2010) accompanied with a progressive top-to-the northeast shearing deformation from the ductile to the brittle fields (Mehl et al., 2005; 2007). The early Eocene exhumation history is preserved in the south-western part of Tinos below a branch of the Vari Detachment. Exhumation of the dome lasted until $9 \mathrm{Ma}$ after the intrusion of the Tinos granodiorite below the same detachment system. The NCDS has accommodated a large part of the exhumation of the northern Cyclades; at least $70 \mathrm{~km}$ of normal sense displacement have been estimated for the OligoMiocene part of the exhumation history (Jolivet et al., 2004a).

3.3 Kea and Kythnos. Among the cold metamorphic domes, some crop out in the Western Cyclades (Kea, Kythnos and Serifos) and their kinematic evolution and timing were documented by recent integrated studies. Kea and Kythnos mostly show the Cycladic Blueschists exhumed below the WCDS (Grasemann and Petrakakis, 2007; Iglseder et al., 2011; Grasemann et al., 2012; Rice et al., 2012). Similarly to the NCDS, the WCDS shows a progressive deformation from ductile to brittle during footwall exhumation, but with an opposite shear sense, top-to-the SW. As one additional difference with the northern Cyclades, the western Cyclades show an intense retrogression of the Cycladic Blueschists in the greenschist-facies and poor preservation of the Eocene HP-LT metamorphism. Kea and Kythnos also form domes of foliation, but they are elongated parallel to the stretching direction showing that a-type domes (Jolivet et al., 2004a) are not restricted to hightemperature environments. The history of exhumation starts in the Eocene like in the whole Cycladic Blueschists and lasts until the Late Miocene for the most recent low-temperature evolution. 
3.4 Serifos. Serifos Island displays a metamorphic core complex and a granodioritic intrusion exhumed below two detachments (Altherr and Siebel, 2002; Grasemann and Petrakakis, 2007; Iglseder et al., 2009; St. Seymour et al., 2009; Tschegg and Grasemann, 2009; Stouraiti et al., 2010; Grasemann et al., 2012). The dome shows both the Cycladic Blueschists and the Cycladic Basement with very few relics of the Eocene HP-LT episode and mostly amphibolite and greenschist-facies parageneses instead. It is thus very different from the low-temperature domes of the northern Cyclades where HP-LT parageneses are well preserved but it does not show pervasive partial melting and migmatites like Naxos, Paros or Mykonos (Vanderhaeghe, 2004; Denèle et al., 2011). The Miocene granodiorite and the dome where exhumed along two branches of the south-dipping WCDS. Radiochronological data suggest that the HP-LT event occurred during the Eocene like in all Cyclades islands but ${ }^{40} \mathrm{Ar} /{ }^{39} \mathrm{Ar}$ ages are partially reset showing no clear plateau and preferred ages between 38 and $32 \mathrm{Ma}$ (Schneider et al., 2011). This partial resetting is likely due to the later intrusion and the activity of low-angle normal faults. Retrogression into the greenschists to amphibolite facies is intense on Serifos and the relict Late Eocene ages are found only in the greenschist-facies rocks in the upper part of the metamorphic core complex. Whether the higher temperature reached in the lower part where amphibolite facies rocks dominate is due to the granitoid intrusion or to a more regional event is unclear. Part of the retrogression and the HT-LP metamorphism are contemporaneous with extension and the activity of the WCDS between 15 and $6 \mathrm{Ma}$, while the granitoid intruded the lower detachment between 11.6 and $9.5 \mathrm{Ma}$ (Iglseder et al., 2011). Kinematic indicators associated with exhumation in the footwall of the two detachments show a top-to-the-south sense of shear while an older stretching lineation, of probable Eocene age, trends more E-W.

\section{4- High-temperature metamorphic core complexes}

High-temperature domes are found mostly in the central and eastern Cyclades and they are all associated with one or several granitoid intrusions (figs 3, 4, 5). In general, the history of the HT dome starts before the intrusions pierces the dome at a later stage, once it has been partly exhumed by the detachments, as shown by the examples of Naxos (Gautier et al., 1993; Vanderhaeghe, 2004) or Tinos (Jolivet et al., 2004a). The most classical ones are represented by two groups of islands: Naxos-Paros and Mykonos-Delos-Rhinia. 
4.1 Naxos and Paros. Naxos-Paros has been described as a metamorphic core complex since the first paper recognizing such structures in the Aegean region (Lister et al., 1984) and several detailed studies were conducted afterwards (Urai et al., 1990; Buick, 1991; Gautier et al., 1993; Koukouvelas and Kokkalas, 2003; Vanderhaeghe, 2004; Duchêne et al., 2006; Martin et al., 2006). It is composed of two domes intruded by a Miocene granodiorite and roofed by a north-dipping detachment. The detachment and the mylonitic foliation are folded in broad antiforms and synforms (Avigad et al., 2001), whose axes trend parallel to the N-S stretching lineation in the mylonitic zone. The dome itself is composed of a core of migmatitic gneiss that belong to the basement of the Cycladic units and metasediments (Jolivet et al., 2004b), and cover series mostly composed of metapelites and marbles, pervasively re-equilibrated under HT-LP conditions after HP-LT (Avigad, 1998) that represent the cover of this basement. Metamorphic isograds are concentric around the migmatitic basement and a steep metamorphic gradient is observed toward the core of the dome. Blueschists parageneses, dated from the Eocene, are found preserved only in the most external parts of the foliation dome (Avigad, 1998). The succession of an Eocene HP-LT metamorphism followed by a HT-LP event of Oligo-Miocene age is clearly illustrated on this example (Altherr et al., 1982). Maximum temperature $\left(650-700^{\circ} \mathrm{C}\right.$ and $\sim 8 \mathrm{kbar}$, Duchène et al. 2006) was reached during exhumation between 23 and $17 \mathrm{Ma}$. The dome was then exhumed until 9-10 Ma and most of displacement along the detachment was achieved between 16 and 8 Ma (Wijbrans and McDougall, 1988; Brichau et al., 2006; Duchêne et al., 2006). The direction of stretching is consistently N-S-trending, thus parallel to the elongation of the dome (a-type dome), and the sense of the shear is top-to-the-north. Both the HT dome and the 12 Ma old granitoid intrusion are sheared in the footwall of the north-dipping detachment. The hanging wall of the detachment is made of a serpentinite unit and overlying sediments deposited from the Early (Late Aquitanian) to Middle Miocene marine sediments (Angelier et al., 1978; Kuhlemann et al., 2004). The list of fossils published in Angelier et al. (1978) shows that the lowermost sediments were deposited between 21 and 19.8 Ma (Late Aquitanian to Early Burdigalian, JP Suc, personal communication), except if some reworking has happened. The age of the first extension is not firmly established. The presence of marine sediments as soon as the Late Aquitanian shows that extension in the Aegean was already underway at this period and was sufficiently advanced to bring the surface below sea water, but whether the Naxos detachment was already active at that time is unknown. John and Howard (1995) and Kuhlemann et al. (2004) conclude to a first extension at $17 \mathrm{Ma}$ based on 
the exhumation history of the dome, which is compatible with the P-T-time history obtained by Duchène et al. (2006).

The HT-LP partially molten gneiss are also observed on the nearby Paros island where the detachment also extends (Papanikolaou, 1979; Gautier et al., 1993; Engel and Reischmann, 1997; Bargnesi et al., 2013). There, the basement yields Carboniferous ages and the main deformation is of Miocene age, with NNE-SSW trending direction of extension and top-to-the NNE sense of shear (Keay and Lister, 2002; Bargnesi et al., 2013). S-type granitoids intruded the basement during extensional shearing at $\sim 16 \mathrm{Ma}$. Extensional shearing deformation was active before $16 \mathrm{Ma}$ and lasted until $\sim 7 \mathrm{Ma}$ and the ductile-brittle transition was crossed at $\sim 12$ Ma. Based on a thermo-chronological study, Bargnesi et al. (2013) conclude that syn-extension sediments were deposited on the hanging wall from 17 to $7 \mathrm{Ma}$ (Bargnesi et al., 2013), which is compatible with the Burdigalian biostratigraphic age of some of these sediments documented by Dermitzakis and Papanikolaou (1980).

4.2 Mykonos, Delos and Rhinia. On the Mykonos-Delos-Rhinia archipelago, another HT dome floors a large I-type granitic laccolith that covers most of Mykonos Island (Faure and Bonneau, 1988; Faure et al., 1991; Lee and Lister, 1992; Denèle et al., 2011). The dome is mostly made of paragneiss belonging to the Cycladic Basement, like on Naxos. Consistent top-to-the east or northeast kinematic indicators are recorded within the dome and the pluton that were exhumed below two branches of the NCDS between 14 and 10 Ma with an offset amounting to ca. $30 \mathrm{~km}$ during this period (Brichau et al., 2008; Lecomte et al., 2010; Denèle et al., 2011; Menant et al., 2013). It is likely that the detachment started to move earlier, as suggested by its western extension on the nearby island of Tinos (Jolivet et al., 2010). No age are available on the migmatitic dome itself, but the proximity with Naxos and the similarity of their deformation histories makes them likely to be coeval. Late Miocene sediment (conglomerate, shales and sandstones) deposition occurred in the hanging wall of the Mykonos Detachment (Sanchez-Gomez et al., 2002; Lecomte et al., 2010).

4.3 Ikaria. Ikaria Island shows one I-type and two S-type Miocene plutons intruding a micaschists, marbles and gneiss dome elongated NE-SW (Boronkay and Doutsos, 1994; Photiades, 2002; Kumerics et al., 2005; Bolhar et al., 2010; Kokkalas and Aydin, 2013). HPLT parageneses are only scarcely preserved within the dome and most of the observed deformation is related to HT-LP metamorphic conditions $\left(600^{\circ} \mathrm{C}\right.$ for less than $\left.8 \mathrm{kbar}\right)$ (Kumerics et al., 2005). Recent estimates (Beaudoin et al., 2015) of the maximum 
temperature reached by metamorphic rocks of the dome with the RSCM method (Beyssac et al., 2002), bracketed between 530 and $630^{\circ} \mathrm{C}$, confirm this conclusion. The dome shows a pervasive top-to-the-north shearing that is also well recorded in the granitic plutons (Kumerics et al., 2005; Beaudoin et al., 2015; Laurent et al., 2015). Exhumation through the ductile-to-brittle transition occurred some 12-11 Ma ago and late exhumation stages are continuously recorded until $6 \mathrm{Ma}$ (Kumerics et al., 2005). The Karkinagrion two-micas granite (S-type) is closely associated with migmatitic gneiss, suggesting that it roots in a HT dome as in Mykonos-Delos or Naxos-Paros (Laurent et al., 2015; Beaudoin et al., 2015). The age of the protolith is at least Palaeozoic, as shown by $\mathrm{U} / \mathrm{Pb}$ on zircons or $\mathrm{Rb} / \mathrm{Sr}$ dating on pegmatite dykes (Martin, 2004; Kumerics et al., 2005), although some of the Palaeozoic zircons found in the metasediments could be of detrital origin. They also show overgrowth indicating that the dome has seen both the Eocene and the Oligo-Miocene event (20-25 Ma, as on Naxos island) (Martin, 2004). The dome could be correlated with the part of Menderes massif that crops out below the Cycladic Blueschists (Kumerics et al., 2005), and thus with the Cycladic Basement (Jolivet et al., 2004b).

All these domes thus usually show a very limited preservation of the Eocene HP-LT parageneses and a strong HT Oligocene and Miocene overprint associated with north-dipping (NCDS) or south- to southwest-dipping (WCDS) detachments. The protoliths belong either to the Cycladic Blueschists or the Cycladic-Menderes Basement. The older evidence for the HT overprint is dated around 20-25 $\mathrm{Ma}$ and the associated deformation and exhumation lasted until 6-8 Ma. In all cases the domes are associated with Miocene intrusions, S-type or I-type granitoids.

\section{5- Granitoids}

5.1. Age of intrusions. Considering a broader region, a clear migration of granitoid emplacement is observed from north to south from the Balkans and the vicinity of the Black Sea to the northern Aegean Sea and northern Anatolia from the Late Cretaceous to the Early Miocene (Ersoy and Palmer, 2013) (figure 3). Granitoid intrusions in the Aegean Sea proper span a shorter period that started some $16 \mathrm{Ma}$ ago in Ikaria to the northeast and ended around $8 \mathrm{Ma}$ in Lavrion, to the southwest, (Skarpelis et al., 1992; Altherr and Siebel, 2002; Brichau et al., 2007; 2008; Liati et al., 2009; Bolhar et al., 2010).

The Cyclades intrusions are all younger than the Oligocene-Early Miocene granitoids found in the Kazdag and Menderes massifs in western Anatolia as well as in the Rhodope 
massif (Dilek et al., 2009). In most of the Rhodope massif intrusions are Eocene except for the Oligo-Miocene Vrondou and Symvolon-Kavala granites (Brun and Sokoutis, 2007; Ersoy and Palmer, 2013). In western Anatolia the northern intrusions are Eocene in age and those intruding the Menderes massif and the Kazdag metamorphic core complex are OligoMiocene. Eocene plutons are diorites, quartz-diorites, granodiorites or syenites before $48 \mathrm{Ma}$ and monzogranites, granodiorites or granites between $48 \mathrm{Ma}$ and $34 \mathrm{Ma}$. In the Kazdag massif, granites, granodiorites or monzonites are dated between 25 and $21 \mathrm{Ma}$ (Dilek et al., 2009). In the Menderes massif, intrusions situated just below the Simav detachment (Egrigöz and Koyunoba) are granites, granodiorites and monzonites and they have provided ages of 21 Ma, while the Baklan granitoid further east is seemingly slightly younger with ages between 18 and $20 \mathrm{Ma}$. The age of the youngest Salihli intrusive in the Menderes massif is not as clear. Available ages range from 21 to $15 \mathrm{Ma}$ and hydrothermal activity has reset some of the ages until $15 \mathrm{Ma}$ (Catlos et al., 2010).

5.2. Petrology and chemistry of Cycladic intrusions. The main granitoid bodies are found on the islands of Ikaria, Mykonos, Tinos, Naxos, Serifos and Kos as well as in Lavrion (figure 3). On Samos, an additional composite system of granitic and granodioritic dykes is observed along the western coast (Mezger and Okrusch, 1985). Keiter et al. (2011) also suggest the possible existence of a Miocene granitoid below the southwestern part of Syros island, which would explain the hydrothermal alteration and silicification observed in the field. The petrology of the I-type intrusions evolves from monzonites in the east (i.e. Samos, Kos, Bodrum) to granodiorites in the west. From west to east, they are: (1) the Lavrion and Serifos intrusions which are medium to high-K granodiorites, (2) Tinos, Mykonos, Delos, Naxos and Thera show high-K low silica granites, (3) Ikaria has high-K high silica granites and (4) Samos, Kos and Bodrum plutons are more affiliated to monzonitic composition (Altherr and Siebel, 2002). In addition, two-micas leucogranites are found in large volumes on Ikaria and the aluminium saturation index is higher for some of the northernmost plutons (Tinos, Delos and Ikaria) (Altherr and Siebel, 2002; Bolhar et al., 2010).

5.3. Source of intrusive magmas. The source of these magmas has been debated in the literature (Altherr and Siebel, 2002; Pe-Piper and Piper, 2002, 2006; Bolhar et al., 2012) and a clear crustal melting component is today ascertained. They derive from a mixing of two sources in variable proportions, an enriched mantle source with low ${ }^{87} \mathrm{Sr}^{86} \mathrm{Sr}_{\mathrm{i}}$ and a crustal source with high ${ }^{87} \mathrm{Sr}^{86} \mathrm{Sr}_{\mathrm{i}}$. These granitoids derive from a variable component of crustal 
melting within a magma extracted from an enriched mantle (Altherr and Siebel, 2002; Stouraiti et al., 2010; Bolhar et al., 2012). Geochemistry of the plutons shows a decrease of the crustal component through time from Ikaria to Kos in the southeast, to Serifos in the southwest or Lavrion in the west. This evolution spans the whole period of plutons emplacement from 16 to $8 \mathrm{Ma}$. It is noticeable that discrete venues of S-type granitoids are found in HT metamorphic core complexes, as on Naxos or Ikaria, as soon as $23 \mathrm{Ma}$ (Pe-Piper and Piper, 2002).

On Naxos, the migmatitic paragneiss of the core of the HT dome could be part of the source of the pluton (Pe-Piper and Piper, 2002) and the Mykonos pluton also roots within a migmatitic dome (Denèle et al., 2011). This is consistent with the occurrence of two large two-micas S-type granites (Xylosyrtis and Karkinagrion) on Ikaria in addition to the I-type Raches granite (Bolhar et al., 2010). A recent survey (Laurent et al., 2015) shows that the Karkinagrion granite is much more voluminous than previously mapped and is closely associated with migmatites. In some examples, the chemistry of the plutons on one given island seems to evolve from felsic to more mafic, as on Serifos for instance, where the granodioritic pluton, as well as the host rocks of the Cycladic Blueschist Unit, are intruded by late basaltic dykes. Late dykes attributed to the Pliocene on Ikaria also originate from lower crustal melting (Baltatzis et al., 2009). Bolhar et al. (2012) conclude that the Ikaria intrusions results from recycling and melting of crustal material due to the injection of basic magmas derived from the mantle. Those juvenile mafic magmas provide the heat necessary to melt the aluminous crustal material, and the evolving proportion of basic material in the melange leads to the different petrographic facies found in the field today.

5.4. Plutons and detachments. These synkinematic plutons intruded the footwall of the Aegean detachments somehow late during their period of activity (Jolivet et al., 2010). On Tinos, the pluton intrudes the Tinos detachment and is affected by the more superficial Livada detachment (Brichau et al. 2007). On Mykonos, the granite intrudes the Upper Cycladic Unit and is intensely sheared along the contact. All this evolution takes place below the Mykonos detachment that is the most superficial branch of the NCDS (Lecomte et al., 2010; Denèle et al., 2011). The NCDS then extends eastward on Ikaria where the Raches granite intrudes the deep branch of the NCDS, the Agios Kirykos detachment, and is sheared by the Gialiskari detachment, similar to the Mykonos detachment (Laurent et al., 2015; Beaudoin et al., 2015). On Naxos, the intrusion pierces the syn-extension migmatitic dome and is then sheared by the main detachment (Gautier et al., 1993). On Serifos also, the granodiorite intrudes the lower 
Meghalo Livadhi detachment and is then sheared by the more superficial Kàvos Kiklopas and Agios Sostis detachments (Tschegg and Grasemann, 2009; Rabillard et al., 2015).

\section{6- Kinematics of the detachment systems}

Over most of the Cycladic archipelago, the detachment kinematics is top-to-the north or northeast (Faure and Bonneau, 1988; Urai et al., 1990; Buick, 1991; Faure et al., 1991; Gautier et al., 1993; Gautier and Brun, 1994b, a; Kumerics et al., 2005; Mehl et al., 2005; 2007; Jolivet et al., 2013) (figs. 5, 6). This is true all along the NCDS in Evvia, Andros, Tinos, Mykonos, Ikaria and Samos. The NCDS then extends eastwards within the Simav detachment (Jolivet et al., 2010; 2013) that has exhumed the northern part of the Menderes massif where migmatites and intrusions are also observed associated with a top-to-the north sense of shear (Is1k et al., 2003; Bozkurt et al., 2011a; 2011b). The same sense of shear is also found on Naxos and Paros further south. Although no detachment crops out on Folegandros, Sikinos or Sifnos and the northern part of Ios, syn-greenschist and partly brittle shearing deformation is recorded with the same top-to-the north or northeast sense of shear (Huet et al., 2009; Augier et al., 2014). A more symmetrical pattern of detachments, top-tothe north and top-to-the south, has been described further south within the massif itself (Hetzel et al., 1995; Gessner et al., 2001).

The Western Cyclades, Kea, Kythnos and Serifos, as well as the Lavrion region, show an opposite sense of shear, top-to-the southwest, below the WCDS (Grasemann and Petrakakis, 2007; Brichau et al., 2010; Iglseder et al., 2011; Grasemann et al., 2012; Rabillard et al., 2014). A top-to-the south detachment has also been described on Ios and Sifnos (Lister et al., 1984; Vandenberg and Lister, 1996; Ring et al., 2011). Huet et al. (2009) have however shown that the top-to-the south shear sense observed on Ios should rather be attributed to an Eocene HP-LT phase of thrusting at the base of the Cycladic Blueschists. On Ios late greenschist-facies shearing in the Cycladic Blueschists Unit are also top-to-the north (Huet et al., 2009). Late brittle top-to-the-south shear senses are observed on Folegandros, Sikinos (Augier et al., 2014) and Sifnos (Ring et al., 2011) clearly reworking the top-to-the north or top-to-the northeast one. This may suggest that the WCDS extends eastward from Serifos offshore these two islands.

Concluding, most of the Cyclades have recorded a top-to-the north sense of shear except for the southwestern part where an opposite sense of shear is observed. The intrusions emplaced during extension have recorded the same distribution of the sense of shear. At the 
scale of the Cyclades the overall shearing pattern is thus more symmetrical in the west than in the centre and northeast (fig. 5). This conclusion is mainly based upon the distribution of kinematic indicators and major detachments. However, quantifying the exact amount of extension on each detachment is not easy. The largest throw on detachments is most likely along the NCDS or the Paros-Naxos Detachment that have accommodated several tens of kilometres of displacement but, according to Grasemann et al. (2012) the WCDS can compare to the northern detachment and they describe extension in the western part of the Aegean Sea as bivergent.

\section{7- Discussion}

A generally accepted view of the evolution of the Aegean region is that slab retreat and lithospheric delamination have put the crust in almost direct contact with the asthenosphere, thus causing partial melting of the lower crust, producing migmatites and S-type granitoids (see for instance Jolivet and Brun, 2010; Brun and Sokoutis, 2010, Ring et al., 2010) and this could suffice to explain a large part of the geological evolution of the Cyclades. However, the above synthesis shows that this evolution is not at all cylindrical and that large variations occur along strike. The difference between the western Aegean on the one hand the Central and Eastern Aegean on the other hand in terms of kinematics , P-T evolution and the shape of domes departs from a 2D evolution. Then, the magmatic evolution is far from simple with a surge of alkaline volcanism in the Eastern Aegean and Western Anatolia from the early Miocene is also a strong departure from a simple 2D evolution. Several authors have already noticed that this surge of volcanism calls for a localized hot mantle that fits a slab-tear model (Dilek and Altunkaynak, 2009; Dilek et al., 2009) and Gessner et al. (2013) have proposed the existence of the West Anatolia Transfert Zone accommodating the slab tear in the crust. We thus now discuss the implications of this 3D evolution.

As shown above, top-to-the north detachments and an asymmetric shearing of exhumed domes thus predominate in the northern and central parts of the Cyclades, while more symmetrical patterns are observed in the southwest during the Oligocene and Miocene. Detachment tectonics and shearing deformation are associated with retrogression of earlier HP-LT parageneses in the greenschist facies in the northwest and higher temperatures, leading to partial melting, in the centre and northeast. High-temperature domes in the central and northeastern Cycladic islands (Mykonos, Paros-Naxos, Ikaria) formed after the 
greenschist domes between 16-17 and $6 \mathrm{Ma}$. This region is thus characterized by more intense finite extension and warmer metamorphic evolution during the Middle and Late Miocene, while other islands further north and south appear colder (Andros, Tinos, Syros, Kea, Kythnos, Serifos, Sifnos, Folegandros, Sikinos and Ios; Fig. 5).

The Cycladic plutons are younger than those found in the Rhodope massif to the north or the Menderes or Kazdag massifs to the east and the formation of HT domes and emplacement of granitoids within them has migrated from northeast to southwest from the Oligocene to the Late Miocene. A migration is observed from $21 \mathrm{Ma}$ to $8 \mathrm{Ma}$ from the east of the Menderes massif to Lavrion. Granitoid intrusions were thus emplaced in the Aegean Sea in a late stage of activity of detachments and exhumation of HT domes within a rather short time window, between 16 and $8 \mathrm{Ma}$, with an apparent migration from Ikaria to the west and south, coeval with a progressive change in the chemistry of plutons. The region where granitoids emplaced is wider than the areal extent of HT domes. Early plutons involve a significant component of lower to middle crustal melting in their source notably giving S-type plutons as in Ikaria and younger ones are closer to a pure mantle source in general. The plutons of Lavrion, Serifos and Tinos are not associated with a HT domes with crustal anatexy. One reason could be that the front of migration of intrusions is ahead of the migration of HT domes which did not have enough time to be exhumed all the way to the surface in these areas before extension migrated outward in the Gulf of Corinth or Western Anatolia regions.

Late HT domes and granitoids in the Aegean and the Menderes suggest that between 25 Ma and $8 \mathrm{Ma}$, a thermal event has provoked re-melting of crustal material coeval with the emplacement of mafic magmas at depth. The HT Cycladic domes started to form before the first Aegean granite intruded the crust. Between 16 and $8 \mathrm{Ma}$, this hot period was at its maximum with the production of granitoid plutons.

One can thus divide the period characterized by backarc extension in four sub-periods: (1) between $\sim 30 \mathrm{Ma}$ and $25 \mathrm{Ma}$, extension was accommodated by the first structures belonging to the NCDS (Tinos, Agios Kirykos detachments, and Simav detachment) and btype domes formed; (2) from $25 \mathrm{Ma}$, while the activity of detachments continued and is still recorded along the NCDS and now also the WCDS (Meghalo Livadhi detachment), hightemperature and low-temperature a-types domes formed in the centre and west of the extending domain and granitoids were emplaced in the north (Southern Rhodope, Kavala) and east (Menderes); (3) from 16 to 8 Ma granitoids plutons emplacement migrated fast across the Cyclades and pierced the first detachments and new detachments took over in more 
superficial crustal levels while the whole Hellenides and part of the Aegean rotated clockwise; (4) after $8 \mathrm{Ma}$, extension was essentially accommodated by brittle structures such as the NCDS in Ikaria and it progressively migrated to finally localise in the external arc (Peloponnese and Crete), western Turkey and the rifts of Corinth and Evvia. Finally, a short event characterized by coexisting N-S extension and E-W compression is recorded around 9 Ma at the transition between the two last periods in the eastern Aegean (Menant et al., 2013).

Figure 7: Schematic interpretation of the coeval fast rotation of the Hellenides (van Hinsbergen et al., 2005) and fast migration of granitoids in the Aegean realm between 16 and $8 \mathrm{Ma}$. The rotation is accommodated by a wide gradient of extension and southward mantle flow encompassing the domain where high-temperature metamorphic domes crop out. See also Ring et al. (1999b) for an earlier suggestion of the existence of a left-lateral transfer zone in the eastern Aegean. This gradient is similar to the West Anatolia Transfer Zone (WATZ) proposed by Gessner et al. (2013). NCDS: North Cycladic Detachment System, WCDS: West Cycladic Detachment System, NPEFS: Naxos-Paros Extensional fault System.

The period of intrusions partly overlaps with the fast rotation of the Hellenic arc from 16 to $8 \mathrm{Ma}$ shown by paleomagnetic data, intrusions starting around $21 \mathrm{Ma}$, earlier than the rotation and both end at the same time (Figure 7). The history of block rotations may be linked with the formation of tears in the slab. The two toroidal cells shown by the GPS velocity field (Pérouse et al., 2012) correlate well with the assumed positions of the two tears and the recent clockwise palaeomagnetic rotations (Bradley et al., 2013) can be explained by the dextral shear distributed across the Central Hellenic Shear Zone (Royden and Papanikolaou, 2011). In the long term, before $\sim 5 \mathrm{Ma}$, the western tear probably did not exist and the main clockwise rotation of the Hellenic arc between and 15 and 8 Ma could be a consequence of the eastern slab tear.

Figure 8: Oblique view on the Cyclades showing the main elements discussed in the text and the relations between mantle flow and exhumation of metamorphic core complexes (MCC) between 17 and 8 Ma. Ikaria, Naxos, Paros and Mykonos MCC's are exhumed above a hot region where hot asthenospheric flow is triggered by the slab tear.

The contemporaneity of the fast rotation of the Hellenides and the emplacement of granitoids suggest a close link between the thermal event implied by the granitic magmas production and the slab tear causing rotation (figs. 8, 9). One can then hypothesized that the progressive slab retreat that had started $35 \mathrm{Ma}$ ago has led to an influx of asthenospheric material below the back-arc region inducing the first heating of the extending Aegean crust. 
This also led to a slow deformation of the Hellenic slab and progressive tearing between 20 Ma and $16 \mathrm{Ma}$. From then on, the slab was freer to move in the mantle and the retreat could accelerate with a pivotal motion about a pole located in north-western Greece or Albania (Kissel and Laj, 1988; van Hinsbergen et al., 2005b; Brun and Sokoutis, 2010; Sternai et al., 2014). This tear opened a window in the slab and the influx of asthenospheric material increased, leading to enhanced thermal anomaly, more crustal melting and mixing with the mafic magmas that were extracted from the mantle. The observed time interval between the peak metamorphism in HT domes and the oldest Aegean granitoids might then be an indication of the time needed to progressively bend, stretched and tear the slab. During the rotation, the first plutons emplaced in the northern end of the Cyclades (Ikaria) and then migrated southward and westward, following the flow of mantle induced by the tear. Approximately $460 \mathrm{~km}$ have been travelled along this direction highly oblique on the direction of extension in 12 Ma giving a velocity of $3.8 \mathrm{~cm} / \mathrm{yr}$, about the same order of magnitude as the present-day displacement of the southern Aegean (GPS) with respect to Eurasia. Taking into account only the Aegean granitoids between 16 and 8 Ma from Ikaria to Serifos or Lavrion, one finds a velocity ranging from 2 to $2.4 \mathrm{~cm} / \mathrm{yr}$, which is approximately the same as the present day rate of extension across Western Anatolia or western Greece. These velocities are estimated along directions that are oblique to the main direction of extension and are thus not much modified by the amount of extension.

Figure 9: An oblique view of the relations between slab tear, rotations and mantle flow below the Aegean between 17 and 8 Ma.

The slab tear induced a faster rotation of the western branch of the arc above the retreating slab. The rotation is a direct consequence of the tear as the slab becomes narrower and thus moves easier in the mantle (the second more recent tear below Corinth has again reduced the width of the slab and made retreat still easier) as was suggested by Wortel and Spakman (1992) or Faccenna et al. (2007). The slab is attached to the west and thus rotates clockwise. This is similar to the propositions of Brun and Sokoutis (2010) or Jolivet et al. (2013). It then implies a component of left-lateral offset across the zone accommodating the differential motion of the two branches of the arc, which is compatible with the presence of atype domes within the hot region and outside and with the left-lateral transfer zone postulated to explain the offset of the Simav detachment and the NCDS (Figs. 7, 8, 9). This transfer zone is similar to the West Anatolia Transfer Zone proposed by Gessner et al. (2013) that also 
results from the underlying slab tear. 3D numerical modelling of the dynamics of extensional domes show that a-type domes form within transtensional step-over or underneath a network of strike-slip faults in regional transtensional setting (Le Pourhiet et al. 2012; 2014). This wrench component could thus explain a part of the N-S "folds" that would result from the formation of a-type domes in a late stage of extension. The presence of a-type domes within the Aegean domain is thus compatible with the wrench component caused by the slab tear at depth and could accommodate the resulting rotation of continental Greece. Localised largescale faults such as the so-called Mid-Cycladic Lineament or the Myrthes-Ikaria Fault have previously been used as major dislocations of the Aegean Sea crust to reconstruct the preextension situation. The existence of such large-scale faults has been postulated to explain differential paleomagnetic rotations on either side (Walcott and White, 1998; van Hinsbergen and Schmid, 2012) or reconstruct the original shape of the North Cycladic Detachment System (Philippon et al., 2012). The exact tectonic significance of the Mid-Cycladic Lineament remains rather enigmatic. It is presented as a boundary between rotating blocks in Walcott and White (1998) or as a detachment in van Hinsbergen and Schmid (2012) and the Myrtes-Ikaria Fault is assumed to be a dextral strike-slip fault in Philippon et al. (2012). In fact, such faults have not been observed and no clear structure such as vertical foliation or clear discontinuities has ever been shown and we think it does not exist as such. Instead, we see a wide gradient of extension in the middle and lower crust that covers a large part of the Aegean Sea. The finite extension increases westward toward the zone of maximum extension in the centre of the Cyclades. In terms of surface kinematic, this scenario leads to a left-lateral displacement of the Aegean relative to Anatolia and is similar to those proposed by Jolivet et al. (2009), Brun and Sokoutis (2010) or Jolivet al. (2013) but does not involve a real series of left-lateral faults because the main deformation is extensional. Deformation is induced by the mantle flowing underneath as illustrated on figures 7 and 8. Dextral faults systems started to localise later than the activity of the detachments, once the westward displacement of Anatolia had started, probably enhanced by the formation of a new slab tear below the Gulf of Corinth (Royden and Papanikolaou, 2011; Jolivet et al., 2013; Menant et al., 2013).

The distribution of kinematic indicators over the whole Aegean domain is also compatible with this scenario. The more pronounced asymmetry of the extensional deformation (mostly top-to-the north) in the centre and east is kinematically compatible with a south-directed mantle flow underneath, assuming a significant coupling between mantle flow and crustal deformation as suggested in Jolivet et al. (2004; 2009) or Sternai et al. 
(2014). In the western Cyclades, where this flow would be less efficient, the asymmetry is less pronounced and the NCDS is taken over in the south by the WCDS.

The GPS velocity field only shows the present-day pattern that is controlled by the two tears. What was exactly the velocity field before the formation of the second tear is impossible to predict. However, paleomagnetic data suggest counterclockwise rotations of part of the Menderes massif and of the eastern Aegean (Kissel and Laj, 1988; Van Hinsbergen, 2010) roughly contemporaneous with the clockwise rotation of the Hellenides, before the formation of the western tear. While the clockwise rotation of the Hellenides can be interpreted as a consequence of retreat and rotation of a large piece of slab still attached to the west, the counterclockwise rotation in the east can be understood as a consequence of the wide diffuse left-lateral gradient of extension induced in the crust by the tear. Part of the differential southward crustal flow between western Anatolia and the Aegean would then be partly accommodated by differential extension and partly by counterclockwise rigid rotations of continental blocks.

Figure 10: Map view and two oblique views of the numerical model of Sternai et al., (2014). Blue domain represents the mantle of the subducting plate and the brown domain continental crust. Brown arrows show the crustal flow at the surface while green arroms show the flow in the mantle. The $N-S$ white line in map view shows the prescribed weak zone in the subducting lithosphere. A: Map view of the surface of the model with the crustal and asthenospheric displacement vectors. B: View from above of the $3 d$ model showing the flow in the asthenospheric mantle and the slab colored with depth (blue to red). C: Oblique 3D view from above. D: Oblique 3D view from below. E: Map view showing the crustal displacement vectors (black arrows and the strain rate) from Sternai et al. (2014).

Finally, a useful comparison (figure 10) can be made with a recently published set of numerical models (Sternai et al., 2014). These models were run to test the respective contribution of crustal and mantle processes to surface deformation. The setup (for details see Sternai et al., 2014) involves an oceanic lithosphere carrying a small continent subducting below a continental lithosphere. This initial setup is not much different from the analogue models of Guillaume et al. (2011) that involved the subduction of a complex plate made of continental crust on one side and oceanic crust on the other side to explore the consequence of a tear on upper plate deformation with a focus on the western tear below the Corinth Rift and the Central Hellenic Shear Zone. Guillaume et al. (2011) conclude that the tear may explain the dextral shear observed in the recent period and possibly the propagation of the North 
Anatolian Fault. In the numerical model of Sternai et al. (2014) a vertical weak zone is prescribed in the oceanic plate parallel to the direction of convergence. This weak zone evolves as a tear during subduction and induces a different behaviour of the subducting slab on either side. The slab "east" of the tear retreats first, until the microcontinent collides with the larger continent. Then the slab "west" of the tear retreats at a faster pace and induces extension in the upper plate limited by a left-lateral zone of to the east. The crustal flow in the upper plate shows a toroidal cell centered within the microcontinent and the velocity increases southward like in the Aegean. A dextral strike-slip shear zone progressively localises between the extruded crust and the more stable crust to the north, resembling the North Anatolian Fault (Fig. 10E). Figure 10 shows new post-processing images of this model (see also figure 4 in Sternai et al., 2014). This figure shows that the crustal and asthenospheric flows are parallel east of the fast moving region but oblique in the west. The velocity of asthenospheric flow is of the same order of magnitude or even larger than crustal flow. This image can be compared with the westward and south-westward migration of granites across the Aegean domain at a velocity of 3-4 cm/yr, which is the same order of magnitude as the GPS velocity measured at the surface. One may then assume that the hot mantle is transported above the tear, leading to crustal melting and formation of the granitoids below the Aegean. The Aegean granitoids would thus sign this asthenospheric flow. This interpretation however should be taken with some caution. The SKS anisotropy map of Paul et al. (2014) does not show such a complex pattern of mantle flow but a simpler geometry. However, a more detailed study by Endrun et al. (2011) suggests a stratification of the anisotropy with an oblique (NE-SW trend) in the lower crust. This oblique trend is parallel to the stretching direction in the western Aegean MCC but oblique on the N-S trending stretching direction of the central and eastern MCC such as Naxos or Sikinos-Folegandros. This suggests that the flow is more complex than initially thought and it could be a consequence of a diverging flow in the asthenosphere as shown in the numerical model. However, the available data set is probably not enough resolved to see the details of the flow in the asthenospheric mantle as the SKS waves anisotropy records a signal integrated over the whole mantle below the station. Besides, the timing of formation of the domes is diachronous, the hot domes being younger than the b-type domes and the seismic anisotropy pattern integrates this complex evolution through time. A different interpretation could be that the migration of granitoids is a consequence of extension progressively migrating westward as suggested by an anonymous reviewer. Some more detailed work on seismic anisotropy would help clarifying this question. 
It should be noted also that the exact geometry of the tear is not precisely known and that different tearing scenarios could lead to the same finite geometry. One constant observation in recent tomographic models (Berk Byriol et al., 2013) is that the high density anomaly seems continuous at the depth of the upper-lower mantle discontinuity. Whether this denotes a really unique slab or a zone of accumulation of slab pieces at that depth is unknown. Where exactly did the tear started is impossible to say with the available data set and thus the tearing mechanism remains largely enigmatic. The geometry suggested for the western tear by Suckale et al. (2009) suggests that the tear there started at shallow depth but we cannot be sure that this can be applied to the tear below the Eastern Aegean. The vertical tear may also be connected to a horizontal break-off scar as suggested in Gessner et al. (2013). Different scenarios are possible to explain these finite geometrical features and we have no clue from the tomographic data set alone to choose between them. What remains is that (1) the fast rotation of the Hellenides, which must be a consequence of the tear below the eastern Aegean, and the formation of high-temperature domes and westward migration of granitoids occurred during the same short time period between 16 and $8 \mathrm{Ma}$ and (2) the asymmetry of deformation in the Cyclades is also associated with this high temperature domain in the crust. This shows that the high temperature anomaly in the crust, which requires a similar hightemperature anomaly in the mantle, has migrated at a fast pace of the Middle Miocene, in turn suggesting that the mantle anomaly has also migrated during that same period, making the link with the tear likely.

\section{8- Conclusion}

The kinematic history of the Cyclades during the Miocene and the distribution of granitoids through time are compatible with an episode of slab tearing postulated earlier on the basis of tomographic models. It also comforts models explaining the distribution and nature of volcanism across western Anatolia by this same slab tear. The timing of paleomagnetic rotations and the distribution of granitoids through space and time allow dating the slab tear between 16 and $8 \mathrm{Ma}$. High-temperature metamorphic domes started to form earlier, as soon as 25-20 Ma. These domes are of a-type, elongated parallel to the regional direction of stretching. This shape of domes is best explained by a gradient of finite extension and resulting left-lateral offset and the presence of an extremely ductile lower crustal unit both consistent with the presence of a tear in the slab underneath. 
Based on geological observations, we therefore propose that progressive tearing (bending, stretching and then tearing) has probably started earlier, as soon as 25-20 Ma when the first high temperature domes formed. This delay between 25 and $16 \mathrm{Ma}$ could reveal the time needed to progressively bend, thin and then totally break the slab. The crust above the tear is characterized by distributed deformation with domes forming within a gradient of finite extension leading to a left-lateral transfer zone controlled by the mantle flow underneath. High-temperature metamorphic domes formed during tearing are of the a-type, elongated parallel to the regional direction of stretching. The $3-4 \mathrm{~cm} / \mathrm{yr}$ velocity of granitoids migration from northeast to southwest could be interpreted as a proxy for the velocity of the mantle flow coeval with the tear. The asymmetry of shear sense associated with detachments in the crust above the tear is more pronounced than further west, suggesting that the mantle shear rate in the tear region is larger and imposes a stronger coupling between the crust and the mantle than in the western part.

Acknowledgments: The authors wish to thank the two anonymous reviewers whose insightful reports were helpful for preparing a better manuscript. Thanks are due also to Jean-Pierre Suc who kindly re-examined the list of fossils published in Angelier et al. (1978) for us. This work has received funding from the European Research Council (ERC) under the seventh Framework Programme of the European Union (ERC Advanced Grant, grant agreement No 290864, RHEOLITH), from the Institut Universitaire de France and from Labex VOLTAIRE.

\section{References}

Altherr, R., Kreuzer, H., Wendt, I., Lenz, H., Wagner, G. A., Keller, J., Harre, W., and Hohndorf, A., 1982, A Late Oligocene/Early Miocene high temperature belt in the anti-cycladic crystalline complex (SE Pelagonian, Greece): Geol. Jb., v. 23, p. 97-164.

Altherr, R., and Siebel, W., 2002, I-type plutonism in a continental back-arc setting: Miocene granitoids and monzonites from the central Aegean Sea, Greece: Contrib. Mineral. Petrol., v. 143, p. 397-415.

Angelier, J., 1976. Sur l'alternance mio-plio-quaternaire de mouvements extensifs et compressifs en Egée orientale: l'île de Samos, Grèce. C. R. Acad. Sci. Paris série D, 283, 463-466.

Angelier, J., Glaçon, G., and Muller, C., 1978, Sur la présence et la position tectonique du Miocène inférieur marin dans l'archipel de Naxos (Cyclades, Grèce): C. R. Acad. Sc. Paris, v. 286, p. 21-24.

Armijo, R., Meyer, B., Hubert, A., Barka, A., 1999. Westward propagation of the north Anatolian into the northern Aegean: timing and kinematics. Geology 27, 267-270.

Aubouin, J., Brunn, J. H., Celet, P., Dercourt, J., Godfriaux, I., and Mercier, J., 1962, Esquisse de la géologie de la Grèce: Bull Soc géol France, v. 2, p. 583-610.

Augier, R., Jolivet, L., Gadenne, L., Lahfid, A., Driussi, O., 2014. Exhumation kinematics of the Cycladic Blueschists and back-arc extension, insights from the Southern Cyclades (Aegean domain, Greece) Tectonics in press. 
Avigad, D., 1998, High-pressure metamorphism and cooling on SE Naxos (Cyclades, Greece): Eur. J. Mineral., v. 10, p. 1309-1319.

Avigad, D., Ziv, A., and Garfunkel, Z., 2001, Ductile and brittle shortening, extensionparallel folds and maintenance of crustal thickness in the Central Aegean: Tectonics, v. 20 , no. 2, p. 277-287.

Baltatzis, E., Kostopoulos, D., Godelitsas, A., Zachariadis, P., and Papanikolaou, D., 2009, Pliocene tourmaline rhyolite dykes from Ikaria Island in the Aegean back-arc region: geodynamic implications: Geodinamica Acta, v. 22, no. 4, p. 189-199, doi:110.3166/ga.3122.3189-3199

Bargnesi, E. A., Stockli, D. F., Mancktelow, N., and Soukis, K., 2013, Miocene core complex development and coeval supradetachment basin evolution of Paros, Greece, insights from (U-Th)/He thermochronometry: Tectonophysics, v. 595-596, p. 165-182, dx.doi.org/110.1016/j.tecto.2012.1007.1015.

Beaudoin, A., Laurent, V., Augier, R., Rabillard, A., Jolivet, L., Arbaret, L., and Menant, A., 2015, The Ikaria Metamorphic Core Complex between the Cyclades and the Menderes massif: submitted.

Berger, A., Schneider, D. A., Grasemann, B., and Stockli, D., 2013, Footwall mineralization during Late Miocene extension along the West Cycladic Detachment System, Lavrion, Greece: Terra Nova, v. 25, no. 3, p. 181-191, doi: 110.1111/ter.12016.

Berk Biryol, C., Beck, S.L., Zandt, G., Özacar, A.A., 2011. Segmented African lithosphere beneath the Anatolian region inferred from teleseismic P-wave tomography. Geophys. J. Int. 184, 1037-1057, doi: 1010.1111/j.1365-1246X.2010.04910.x.

Beyssac, O., Goffé, B., Chopin, C., Rouzaud, J.N., 2002. Raman spectra of carbonaceous material from metasediments : a new geothermometer. J. Metam. Geol. 20, 859-871.

Blake, M. C., Bonneau, M., Geyssant, J., Kienast, J. R., Lepvrier, C., Maluski, H., and Papanikolaou, D., 1981, A geological reconnaissance of the Cyclacic blueschist belt, Greece: Bull. geol. Soc. Amer., v. 92, p. 247-254.

Bolhar, R., Ring, U., and Allen, C. M., 2010, An integrated zircon geochronological and geochemical investigation into the Miocene plutonic evolution of the Cyclades, Aegean Sea, Greece: Part 1: Geochronology: Contrib Mineral Petrol, v. 160, p. 719 742, DOI 710.1007/s00410-00010-00504-00414.

Bolhar, R., Ring, U., Kemp, A. I. S., Whitehouse, M. J., Weaver, S. D., Woodhead, J. D., Uysal, I. T., and Turnbull, R., 2012, An integrated zircon geochronological and geochemical investigation into the Miocene plutonic evolution of the Cyclades, Aegean Sea, Greece: part 2: geochemistry: Contr. Miner. Petrol., v. 164, p. 915-933.

Bonev, N., Burg, J. P., and Ivanov, Z., 2006, Mesozoic-tertiary structural evolution of an extensional gneiss dome - the Kesebir-Kardamos dome, eastern Rhodope (Bulgaria, Greece): Int Jour. Earth Sci., v. 95, p. 318-340.

Bonneau, M., and Kienast, J. R., 1982, Subduction, collision et schistes bleus: exemple de l'Egée, Grèce: Bull. Soc. géol. France, v. 7, p. 785-791.

Boronkay, K., and Doutsos, T., 1994, Transpression and transtension in different structural levels in the Central Aegean region: J. Struct. Geol., v. 16, p. 1555-1573.

Bozkurt, E., and Oberhänsli, R., 2001, Menderes Massif (Western Turkey): structural, metamorphic and magmatic evolution - a synthesis: Int. J. Earth Sciences, v. 89, p. 679-708.

Bozkurt, E., Satır, M., and Bugdaycioglu, C., 2011a, Surprisingly young Rb/Sr ages from the Simav extensional detachment fault zone, northern Menderes Massif, Turkey: Journal of Geodynamics, v. 52, p. 406-431.

Bozkurt, E., Satır, M., and Buğdaycıoğlu, C., 2011b, Dating a detachment fault by Rb-Sr geochronology: a case study from the Simav detachment fault and its tectonic 
implications for the evolution of the northern Menderes Massif (Western Turkey): submitted paper.

Bradley, K. E., Vassilakis, E., Hosa, A., and Weiss, B. P., 2013, Segmentation of the Hellenides recorded by Pliocene initiation of clockwise block rotation in Central Greece: Earth Planet. Sci. Lett., v. 362, p. 6-19.

Brichau, S., Ring, U., Carter, A., Bolhar, R., Monié, P., Stockli, D., and Brunel, M., 2008, Timing, slip rate, displacement and cooling history of the Mykonos detachment footwall, Cyclades, Greece, and implications for the opening of the Aegean Sea basin: J. Geol. Soc. London, v. 165, p. 263-277.

Brichau, S., Ring, U., Carter, A., Monie, P., Bolhar, R., Stockli, D., and Brunel, M., 2007, Extensional faulting on Tinos Island, Aegean Sea, Greece: How many detachments?: Tectonics, v. 26, p. TC4009, doi:4010.1029/2006TC001969.

Brichau, S., Ring, U., Ketcham, R. A., Carter, A., Stockli, D., and Brunel, M., 2006, Constraining the long-term evolution of the slip rate for a major extensional fault system in the central Aegean, Greece, using thermochronology Earth and Pl. Sc. Letters, v. 241, p. 293-306.

Brichau, S., Thomson, S., and Ring, U., 2010, Thermochronometric constraints on the tectonic evolution of the Serifos detachment, Aegean Sea, Greece: Int J Earth Sci (Geol Rundsch), v. 99, p. 379-393. DOI 310.1007/s00531-00008-00386-00530.

Bröcker, M., Baldwin, S., and Arkudas, R., 2013, The geological significance of 40Ar/39Ar and $\mathrm{Rb}-\mathrm{Sr}$ white mica ages from Syros and Sifnos, Greece: a record of continuous (re)crystallization during exhumation?: J. Metam. Geol., v. 31, p. 629-646; doi:610.1111/jmg.12037.

Bröcker, M., Bieling, D., Hacker, B., and Gans, P., 2004, High-Si phengite records the time of greenschist facies overprinting: implications for models suggesting megadetachments in the Aegean Sea: J. Metam. Geol., v. 22, p. 427-442, doi:410.1111/j.1525-1314.2004.00524.x.

Bröcker, M., and Franz, L., 2006, Dating metamorphism and tectonic juxtaposition on Andros Island (Cyclades, Greece): results of a Rb-Sr study: Geol. Mag., v. 143, no. 5, p. 609620, doi:610.1017/S001675680600241X.

Brun, J. P., and Faccenna, C., 2008, Exhumation of high-pressure rocks driven by slab rollback: Earth and Planetary Sciences Letters, v. 272, p. 1-7; doi:10.1016/j.epsl.2008.1002.1038

Brun, J. P., and Sokoutis, D., 2007, Kinematics of the Southern Rhodope Core Complex (North Greece): International Journal of Earth Science, v. DOI 10.1007/s00531-0070174-2.

-, 2010, 45 m.y. of Aegean crust and mantle flow driven by trench retreat: Geology, v. 38, no. 9, p. 815-818; doi: 810.1130/G30950.30951.

Brunn, J. H., Argyriadis, I., Ricou, L. E., Poisson, A., Marcoux, J., and de Graciansky, P. C., 1976, Eléments majeurs de liaison entre Taurides et Hellénides: Bull. Geol. Soc. France, v. 18, no. 2, p. 481-497.

Buick, I. S., 1991, Mylonite fabric development on Naxos, Greece: J. Struct. geol., v. 13, p. 643-655.

Burg, J. P., 2011, Rhodope: From Mesozoic convergence to Cenozoic extension. Review of petro-structural data in the geochronological frame: Journal of the Virtual Explorer, v. 39 p. Paper 1.

Carminati, E., Wortel, M. J. R., Spakman, W., and Sabadini, R., 1998, The role of slab detachment processes in the opening of the western-central Mediterranean basins: some geological and geophysical evidence: Earth Planet. Sci. Lett., v. 160, p. 651-665. 
Catlos, E. J., Baker, C., Sorensen, S. S., Çemen, I., and Hançer, M., 2010, Geochemistry, geochronology, and cathodoluminescence imagery of the Salihli and Turgutlu granites (central Menderes Massif, western Turkey): Implications for Aegean tectonics: Tectonophysics, v. 488, p. 110-130, doi:110.1016/j.tecto.2009.1006.1001.

Cavazza, W., Okay, A.I., Zattin, M., 2009. Rapid early-middle Miocene exhumation of the Kazdağ metamorphic core complex (Western Anatolia). Int J Earth Sci (Geol Rundsch) 98, 1935-1947.

de Boorder, H., Spakman, W., White, S. H., and Wortel, M. J. R., 1998, Late Cenozoic mineralization, orogenic collapse and slab detachment in the European Alpine Belt: Earth and Pl. Sc. Letters, v. 164, p. 569-575.

Denèle, Y., Lecomte, E., Jolivet, L., Lacombe, O., Labrousse, L., Huet, B., and Le Pourhiet, L., 2011, Granite intrusion in a metamorphic core complex: the example of the Mykonos laccolith (Cyclades, Greece): Tectonophysics, v. 501, p. 52-70, doi:10.1016/j.tecto.2011.1001.1013.

Dermitzakis, M., Papanikolaou, D., 1980. The molasse of Paros Island, Aegean Sea. Ann. Naturhist. Mus. Wien 83.

Dercourt, J., Zonenshain, L. P., Ricou, L. E., Kuzmin, V. G., Le Pichon, X., Knipper, A. L., Grandjacquet, C., Sbortshikov, I. M., Geyssant, J., Lepvrier, C., Pechersky, D. H., Boulin, J., Sibuet, J. C., Savostin, L. A., Sorokhtin, O., Westphal, M., Bazhenov, M. L., Lauer, J. P., and Biju-Duval, B., 1986, Geological evolution of the Tethys belt from the Atlantic to the Pamir since the Lias: Tectonophysics, v. 123, p. 241-315.

Dilek, Y., and Altunkaynak, S., 2009, Geochemical and temporal evolution of Cenozoic magmatism in western Turkey: mantle response to collision, slab break-off, and lithospheric tearing in an orogenic belt, in van Hinsbergen, D. J. J., Edwards, D. J. J., and Govers, R., eds., Collision and Collapse at the Africa-Arabia-Eurasia Subduction Zone, Volume 311: London, The Geological Society, p. 213-233.

Dilek, Y., Altunkaynak, S., and Öner, Z., 2009, Syn-extensional granitoids in the Menderes core complex and the late Cenozoic extensional tectonics of the Aegean province, in Ring, U., and Wernicke, B., eds., Extending a continent: architecture, rheology and heat budget, Volume 321: London, Geological Society, Special Publications, p. 197223.

Doglioni, C., Agostini, S., M Crespi, Innocenti, F., Manetti, P., Riguzzi, F., and Savasçin, Y., 2002, On the extension in western Anatolia and the Aegean sea: Journal of the Virtual Explorer, v. 7, p. 167-181.

Duchêne, S., Aïssa, R., and Vanderhaeghe, O., 2006, Pressure-Temperature-time Evolution of Metamorphic Rocks from Naxos (Cyclades, Greece): constraints from Thermobarometry and Rb/Sr dating Geodynamica Acta, v. 19, no. 5, p. 299-319.

Engel, M., and Reischmann, T., 1997, Geochronological data on granitoid gneiss from paros, greece, obtained by single zircon Pb evaporation: Terra Nova, v. 9, p. 463.

Ersoy, E. Y., and Palmer, M. R., 2013, Eocene-Quaternary magmatic activity in the Aegean: Implications for mantle metasomatism and magma genesis in an evolving orogeny: Lithos, v. 180-181, p. 5-24, dx.doi.org/10.1016/j.lithos.2013.1006.1007.

Faccenda, M., and Capitanio, F. A., 2012, Development of mantle seismic anisotropy during subduction-induced 3-D flow: Geophys Res. Lett., v. 39, p. L11305, doi:11310.11029/12012GL051988.

Faccenna, C., and Becker, T. W., 2010, Shaping mobile belts by small-scale convection: Nature, v. 465, no. 3, p. 602-605, doi:610.1038/nature09064.

Faccenna, C., Bellier, O., Martinod, J., Piromallo, C., Regard, V., 2006. Slab detachment beneath eastern Anatolia: A possible cause for the formation of the North Anatolian fault. Earth and Planetary Science Letters 242, 85- 97. 
Faccenna, C., Civetta, L., M D'Antonio, Funiciello, F., Margheriti, L., and Piromallo, C., 2005, Constraints on mantle circulation around the deforming Calabrian slab: Geophys Res. Lett., v. 32, p. L06311, doi:06310.01029/02004GL021874.

Faccenna, C., Funiciello, F., Civetta, L., D’Antonio, M., Moroni, M., and Piromallo, C., 2007, Slab disruption, mantle circulation, and the opening of the Tyrrhenian basins, in Beccaluva, L., Bianchini, G., and Wilson, M., eds., Cenozoic Volcanism in the Mediterranean Area, Volume 418, p. 153-169, doi: 110.1130/2007.2418(1108).

Faccenna, C., Jolivet, L., Piromallo, C., and Morelli, A., 2003, Subduction and the depth of convection in the Mediterranean mantle: J. Geophys. Res., v. 108, no. B2, p. 2099, doi: 2010.1029/2001JB001690.

Faccenna, C., Piromallo, C., Crespo-Blanc, A., Jolivet, L., and Rossetti, F., 2004, Lateral slab deformation and the origin of the Western Mediterranean arcs: Tectonics, v. 23, p. doi:10.1029/2002TC001488.

Faure, M., and Bonneau, M., 1988, Données nouvelles sur l'extension néogène de l'Egée: la déformation ductile du granite miocène de Mykonos (Cyclades, Grèce): $C$. R. Acad. Sci. Paris, v. 307, p. 1553-1559.

Faure, M., Bonneau, M., and Pons, J., 1991, Ductile deformation and syntectonic granite emplacement during the late Miocene extension of the Aegean (Greece): Bull. Soc. géol. France, v. 162, p. 3-12.

Funiciello, F., Faccenna, C., Giardini, D., and Regenauer-Lieb, K., 2003, Dynamics of retreating slabs: 2. insights from three-dimensional laboratory experiments: J. Geophys. Res., v. 108, no. B4, p. 2207, doi:2210.1029/2001JB000896.

Funiciello, F., Moroni, M., Piromallo, C., Faccenna, C., Cenedese, A., and Bui, H. A., 2006, Mapping mantle flow during retreating subduction: Laboratory models analyzed by feature tracking: J. Geophys. Res., v. 111, p. B03402, doi:03410.01029/02005JB003792.

Fytikas, M., Innocenti, F., Manetti, P., Mazzuoli, R., Peccerillo, A., and Villari, L., 1984, Tertiary to Quaternary evolution of volcanism in the Aegean region, in Dixon, J. E., and Robertson, A. H. F., eds., The geological evolution of the eastern Mediterranean, Volume 17: London, Geological Society, p. 687-699.

Gautier, P., and Brun, J. P., 1994a, Crustal-scale geometry and kinematics of late-orogenic extension in the central Aegean (Cyclades and Evvia island): Tectonophysics, v. 238, p. 399-424.

-, 1994b, Ductile crust exhumation and extensional detachments in the central Aegean (Cyclades and Evvia islands): Geodinamica Acta, v. 7, no. 2, p. 57-85.

Gautier, P., Brun, J. P., and Jolivet, L., 1993, Structure and kinematics of upper Cenozoic extensional detachement on Naxos and Paros (Cyclades Islands, Greece): Tectonics, v. 12, p. 1180-1194.

Gautier, P., Brun, J.P., Moriceau, R., Sokoutis, D., Martinod, J., Jolivet, L., 1999. Timing, kinematics and cause of Aegean extension: a scenario based on a comparison with simple analogue experiments. Tectonophysics 315, 31-72.

Gesret, A., Laigle, M., Diaz, J., Sachpazi, M., Charalampakis, M., and Hirn, A., 2011, Slab top dips resolved by teleseismic converted waves in the Hellenic subduction zone: Geophys Res. Lett., v. 38, p. L20304, doi:20310.21029/22011GL048996.

Gessner, K., Gallardo, L.A., Markwitz, V., Ring, U., Thomson, S.T., 2013. What caused the denudation of the Menderes Massif: Review of crustal evolution, lithosphere structure, and dynamic topography in southwest Turkey. Gondwana Research 24, 243-274, http://dx.doi.org/210.1016/j.gr.2013.1001.1005. 
Gessner, K., Ring, U., Johnson, C., Hetzel, R., Passchier, C. W., and Güngör, T., 2001, An active bivergent rolling-hinge detachment system: Central Menderes metamorphic core complex in Western Turkey: Geology, v. 29, no. 7, p. 611-614.

Govers, R., and Wortel, M. J. R., 2005, Lithosphere tearing at STEP faults: Response to edges of subduction zones: Earth and Planet. Sci. Lett., v. 236 p. 505- 523.

Grasemann, B., and Petrakakis, K., 2007, Evolution of the Serifos Metamorphic Core Complex, in Lister, G., and Foster, M., eds., Inside the Aegean Core Complexes, Volume Paper 10.

Grasemann, B., Schneider, D. A., Stockli, D. F., and Iglseder, C., 2012, Miocene bivergent crustal extension in the Aegean: evidence from the western Cyclades (Greece): Lithosphere, p. doi: 10.1130/L1164.1131.

Guillaume, B., Husson, L., Funiciello, F., Faccenna, C., 2013. The dynamics of laterally variable subductions: laboratory models applied to the Hellenides. Solid Earth 4, 179200, doi:110.5194/se-5194-5179-2013.

Hejl, E., Riedl, H., and Weingartner, H., 2002, Post-plutonic unroofing and morphogenesis of the Attic-Cycladic complex (Aegea, Greece): Tectonophysics, v. 349, p. 37-56.

Henjes-Kunst, F., Altherr, R., Kreuzer, H., and Hansen, B. T., 1988, Disturbed U-Th-Pb systematics of young zircons and uranothites: the case of the Miocene Aegean granitoids (Greece): Chemical Geology, v. 73, p. 125-145.

Hetzel, R., Passchier, C. W., Ring, U., and Dora, O. O., 1995, Bivergent extension in orogenic belts: the Menderes massif (southwestern Turkey): Geology, v. 23, p. 455458.

Huet, B., Labrousse, L., and Jolivet, L., 2009, Thrust or detachment? Exhumation processes in the Aegean: insight from a field study on Ios (Cyclades, Greece): Tectonics, v. 28, p. TC3007, doi:3010.1029/2008TC002397.

Huet, B., Labrousse, L., Monié, P., Malvoisin, B., and Jolivet, L., 2014, Coupled phengite 40Ar-39Ar geochronology and thermobarometry: P-T-t evolution of Andros Island (Cyclades, Greece): submitted.

Iglseder, C., Grasemann, B., Rice, A. H. N., Petrakakis, K., and Schneider, D. A., 2011, Miocene south directed low-angle normal fault evolution on Kea (West Cycladic Detachment System, Greece): Tectonics, v. 30, p. TC4013, doi:4010.1029/2010TC002802.

Iglseder, C., Grasemann, B., Schneider, D. A., Petrakakis, K., Miller, C., Klötzli, U. S., M Thöni , Zámolyi, A., and Rambouseka, C., 2009, I and S-type plutonism on Serifos (W-Cyclades, Greece): Tectonophysics, v. 473, p. 69-83, doi:10.1016/j.tecto.2008.1009.1021

Isık, V., Seyitoglua, G., and Cemen, I., 2003, Ductile-brittle transition along the Alaßsehir detachment fault and its structural relationship with the Simav detachment fault, Menderes massif, western Turkey: Tectonophysics v. 374, p. 1-18.

Jacobshagen, V., Dürr, S., Kockel, F., Kopp, K. O., Kowalczyk, G., Berckhemer, H., and Büttner, D., 1978, Structure and geodynamic evolution of the Aegean region, in Cloos, H., Roeder, D., and Schmidt, K., eds., Alps, Apennines, Hellenides, Volume report 38: Stuttgart, IUGG, p. 537-564.

John, B.E., Howard, K.A., 1995. Rapid extension recorded by cooling-age patterns and brittle deformation, Naxos, Greece. J. Geoph. Res. 100, 9969-9979.

Jolivet, L., and Brun, J. P., 2010, Cenozoic geodynamic evolution of the Aegean region: Int. J. Earth Science, v. 99, p. 109-138, DOI: 110.1007/s00531-00008-00366-00534.

Jolivet, L., and Faccenna, C., 2000, Mediterranean extension and the Africa-Eurasia collision: Tectonics, v. 19, no. 6, p. 1095-1106. 
Jolivet, L., Faccenna, C., Goffé, B., Burov, E., and Agard, P., 2003, Subduction tectonics and exhumation of high-pressure metamorphic rocks in the Mediterranean orogens: Am. J. Science, v. 303, p. 353-409.

Jolivet, L., Faccenna, C., Huet, B., Labrousse, L., Le Pourhiet, L., Lacombe, O., Lecomte, E., Burov, E., Denèle, Y., Brun, J. P., Philippon, M., Paul, A., Salaün, G., Karabulut, H., Piromallo, C., Monié, P., Gueydan, F., Okay, A. I., Oberhänsli, R., Pourteau, A., Augier, R., Gadenne, L., and O Driussi, O., . . ,. 2013, Aegean tectonics: progressive strain localisation, slab tearing and trench retreat: Tectonophysics, v. 597-598, p. 1-33, doi:10.1016/j.tecto.2012.1006.1011.

Jolivet, L., Faccenna, C., and Piromallo, C., 2009, From Mantle to crust: stretching the Mediterranean: Earth Planet. Sci. lett., v. 285, p. 198-209, doi:110.1016/j.epsl.2009.1006.1017

Jolivet, L., Famin, V., Mehl, C., Parra, T., Aubourg, C., Hébert, R., and Philippot, P., 2004a, Progressive strain localisation, boudinage and extensional metamorphic complexes, the Aegean Sea case, in Whitney, D. L., Teyssier, C., and Siddoway, C. S., eds., Gneiss domes in orogeny: Boulder, Colorado, Geological Society of America, p. 185210.

Jolivet, L., Lecomte, E., Huet, B., Denèle, Y., Lacombe, O., Labrousse, L., Le Pourhiet, L., and Mehl, C., 2010, The North Cycladic Detachment System: Earth and Planet. Sci. Lett., v. 289 p. 87-104, doi:110.1016/j.epsl.2009.1010.1032.

Jolivet, L., Rimmelé, G., Oberhänsli, R., Goffé, B., and Candan, O., 2004b, Correlation of syn-orogenic tectonic and metamorphic events in the Cyclades, the Lycian Nappes and the Menderes massif, geodynamic implications: Bull. Geol. Soc. France, v. 175, no. 3, p. 217-238.

Keay, S., and Lister, G., 2002, African provenance for the metasediments and metaigneous rocks of the Cyclades, Aegean Sea, Greece: Geology, v. 30, no. 3, p. 235-238.

Keay, S., Lister, G., and Buick, I., 2001, The timing of partial melting, Barrovian metamorphism and granite intrusion in the Naxos metamorphic core complex, Cyclades, Aegean Sea, Greece: Tectonophysics, v. 342, p. 275-312.

Keiter, M., Ballhaus, C., and Tomaschek, F., 2011, A new geological map of the Island of Syros (Aegean Sea, Greece): Implications for lithostratigraphy and structural history of the Cycladic Blueschist Unit: Geological Society of America Special Paper, v. 481, p. doi:10.1130/2011.2481.

Kissel, C., and Laj, C., 1988, The Tertiary geodynamic evolution of the Aegean arc: a paleomagnetic reconstruction: Tectonophysics, v. 146, p. 183-201.

Kokkalas, S., and Aydin, A., 2013, Is there a link between faulting and magmatism in the south-central Aegean Sea?: Geol. Mag., v. 150, no. 2, p. 193-224, doi:110.1017/S0016756812000453.

Koukouvelas, I. K., and Kokkalas, S., 2003, Emplacement of the Miocene west Naxos pluton (Aegean Sea, Geece): a structural study: Geol. Mag., v. 140, no. 1, p. 45-61.

Kuhlemann, J., Frisch, W., Dunkl, I., Kázmér, M., and Schmiedl, G., 2004, Miocene siliciclastic deposits of Naxos Island: Geodynamic and environmental implications for the evolution of the southern Aegean Sea (Greece), in Bernet, M., and Spiegel, C., eds., Detrital thermochronology - Provenance analysis, exhumation, and landscape evolution of mountain belts:, Volume 378, Geological Society of America, p. 51-65.

Kumerics, C., Ring, U., Brichau, S., Glodny, J., and Monié, P., 2005, The extensional Messaria shear zone and associated brittle detachment faults, Aegean Sea, Greece: Journal of the Geological Society, v. 162, no. 4, p. 701-721.

Laurent, V., Beaudoin, A., Jolivet, L., Arbaret, L., Augier, R., Rabillard, A., 2015. Interactions between extensional shear zones and syn-tectonic granite intrusion: the 
example of Ikaria island (Cyclades, Greece). Tectonophysics 651-652, 152-171, http://dx.doi.org/110.1016/j.tecto.2015.1003.1020.

Le Pourhiet, L., Huet, B., May, D., Labrousse, L., and Jolivet, L., 2012, Kinematic interpretation of the 3D shapes of metamorphic core complexes: Geochem. Geophys. Geosyst, v. 13(9), p. Q09002, doi:09010.01029/02012GC004271.

Le Pourhiet, L., Huet, B., Traoré, N., 2014. Links between long-term and short-term rheology of the lithosphere: Insights from strike-slip fault modelling. Tectonophysics in press.

Lecomte, E., Jolivet, L., Lacombe, O., Denèle, Y., Labrousse, L., and Le Pourhiet, L., 2010, Geometry and kinematics of a low-angle normal fault on Mykonos island (Cyclades, Greece): evidence for slip at shallow dip: Tectonics, v. 29, p. TC5012, doi:5010.1029/2009TC002564.

Lee, J., and Lister, G. S., 1992, Late Miocene ductile extension and detachment faulting, Mykonos, Greece: Geology, v. 20, p. 121-124.

Liati, A., Skarpelis, N., and Pe-Piper, G., 2009, Late Miocene magmatic activity in the AtticCycladic Belt of the Aegean (Lavrion, SE Attica, Greece): implications for the geodynamic evolution and timing of ore deposition: Geol. Mag., v. 146, no. 5, p. 732742, doi:710.1017/S0016756809006438.

Lin, F. C., Ritzwoller, M. H., Yang, Y., Moschetti, M. P., and Fouch, M. J., 2011, Complex and variable crustal and uppermost mantle seismic anisotropy in the western United States: Nature Geoscience, v. 14, p. 55-61, DOI: 10.1038/NGEO1036.

Lister, G. S., Banga, G., and Feenstra, A., 1984, Metamorphic core complexes of cordilleran type in the Cyclades, Aegean Sea, Greece: Geology., v. 12, p. 221-225.

Martin, L., 2004, Signification des âges U-Pb sur zircon dans l'histoire métamorphique de Naxos et Ikaria (Cyclades, Grèce)Thèse de Doctorat]: Université Henri Poincaré, 266 p.

Martin, L., Duchêne, S., Deloule, E., and Vanderhaeghe, O., 2006, The isotopic composition of zircon and garnet: A record of the metamorphic history of Naxos, Greece: Lithos, v. 87, no. 3-4, p. 174-192.

Massari, F., and Prosser, G., 2013, Late Cenozoic tectono-stratigraphic sequences of the Crotone Basin: insights on the geodynamic historyoftheCalabrianarcandTyrrhenianSea: Basin Research, v. 25, p. 26-51, doi: 10.1111/j.1365-2117.2012.00549.x.

McClusky, S., Balassanian, S., Barka, A., Demir, C., Ergintav, S., Georgiev, I., Gurkan, O., Hamburger, M., Hurst, K., Kahle, H., Kastens, K., Kekelidze, G., king, R., Kotzev, V., Lenk, O., Mahmoud, S., Mishin, A., Nadariya, M., Ouzonis, A., Paradissis, D., Peter, Y., Prilepin, M., Reilinger, R., Sanli, I., Seeger, H., Tealeb, A., Toksöz, M. N., and Veis, G., 2000, Global Positioning System constraints on plate kinematics and dynamics in the eastern Mediterranean and Caucasus: J. Geophys. Res., v. 105, p. 5695-5720.

Mehl, C., Jolivet, L., and Lacombe, O., 2005, From ductile to brittle: evolution and localization of deformation below a crustal detachment (Tinos, Cyclades, Greece): Tectonics, v. 24, p. TC4017, doi:4010.1029/2004TC001767.

Mehl, C., Jolivet, L., Lacombe, O., Labrousse, L., and Rimmelé, G., 2007, Structural evolution of Andros island (Cyclades, Greece): a key to the behaviour of a flat detachment within an extending continental crust, in Taymaz, T., Dilek, Y., and Ylmaz, Y., eds., The geodynamics of the Aegean and Anatolia, Volume 291: London, Geological Society, p. 41-73, DOI: 10.1144/SP1291.1143 03058719/1107/\$1115.1100. 
Menant, A., Jolivet, L., Augier, R., and Skarpelis, N., 2013, The North Cycladic Detachment System and associated mineralization, Mykonos, Greece: insights on the evolution of the Aegean domain: Tectonics, v. 32, p. 433-452, doi:410.1002/tect.20037.

Mezger, K., and Okrusch, M., 1985, Metamorphism of a variegated sequence at Kallithea, Samos, Greece: Tschermaks Mineralogische und Petrographische Mitteilungen, v. 34, p. 67-82.

Moresi, L., Betts, P. G., Miller, M. S., and Cayley, R. A., 2014, Dynamics of continental accretion: Nature, v. 508, p. 245-248; doi:210.1038/nature13033.

Moriceau, R., 2000, Evolution du massif métamorphique du Rhodope (Grèce, Bulgarie) dans le contexte alpin. Structures, cinématique et origine de la déformation ductileThèse de doctorat]: Université de Rennes I, 537 p.

Morris, A., and Anderson, A., 1996, First paleaomagnetic results from the Cycladic Massif, Greece, and their implications for Miocene extension directions and tectonic models in the Aegean: Earth Planet. Sci. Lett., v. 142, p. 397-408.

Okay, A.I., Satir, M., 2000. Coeval plutonism and magmatism in a latest Oligocene metamorphic core complex in Northwest Turkey. Geol.Mag. 137, 495-516.

Okay, A., and Tüysüz, O., 1999, Tethyan sutures of northern Turkey, in Durand, B., Jolivet, L., Horvath, F., and Séranne, M., eds., The Mediterranean basins: Tertiary extension within the alpine orogen, Volume 156: London, Geological Society, p. 475-515.

Omrani, J., Agard, P., Whitechurch, H., Benoit, M., Prouteau, G., and Jolivet, L., 2008, Arcmagmatism and subduction history beneath the Zagros Mountains, Iran: A new report of adakites and geodynamic consequences: Lithos, v. 106, no. 3-4, p. 380-398.

Papanikolaou, D. J., 1979, Contribution to the geology of the Aegean Sea: the island of Paros: Ann. Géol. Pays Hellén., v. 30, p. 65-96.

Papanikolaou, D. J., and Royden, L. H., 2007, Disruption of the Hellenic arc: Late Miocene extensional detachment faults and steep Pliocene-Quaternary normal faults-Or what happened at Corinth?: Tectonics v. 26, TC5003, doi:10.1029/2006TC002007.

Parra, T., Vidal, O., and Jolivet, L., 2002, Relation between deformation and retrogression in blueschist metapelites of Tinos island (Greece) evidenced by chlorite-mica local equilibria: Lithos, v. 63, p. 41-66.

Paul, A., Karabulut, H., Mutlu, A. K., and Salaün, G., 2014, A comprehensive and densely sampled map of shear-wave azimuthal anisotropy in the Aegean-Anatolia region: Earth and Planetary Science Letters v. 389 p. 14-22, dx.doi.org/10.1016/j.epsl.2013.1012.1019.

Pe-Piper, G., and Piper, D. J. W., 2002, The igneous rocks of Greece. The anatomy of an orogen, Berlin-Stuttgart, Gebrüder Borntraeger, 573 p.:

-, 2006, Unique features of the Cenozoic igneous rocks of Greece, in Dilek, Y., and Pavlides, S., eds., Postcollisional tectonics and magmatism in the Mediterranean region and Asia, Volume 409, Geological Society of America, p. 259-282,doi: 210.1130/2006.2409(1114).

-, 2007, Neogene back-arc volcanism of the Aegean: new insights into the relationship between magmatism and tectonics, in Beccaluva, L., and Bianchini, G., eds., Cenozoic Volcanism in the Mediterranean Area, Volume 418, Geological Society of America, p. 17-31, doi: 10.1130/2007.2418(1102).

Pérouse, E., Chamot-Rooke, N., Rabaute, A., Briole, P., Jouanne, F., Georgiev, I., and Dimitrov, D., 2012, Bridging onshore and offshore present-day kinematics of central and eastern Mediterranean: Implications for crustal dynamics and mantle flow: Geochem. Geophys. Geosyst, v. 13, no. 9, p. Q09013, doi:09010.01029/02012GC004289. 
Philippon, M., Brun, J. P., and Gueydan, F., 2012, Deciphering subduction from exhumation in the segmented Cycladic Blueschist Unit (Central Aegean, Greece): Tectonophysics, v. 524-525, p. 116-134.

Philippon, M., Brun, J.P., Gueydan, F., Sokoutis, D., 2014. The interaction between Aegean back-arc extension and Anatolia escape since Middle Miocene. Tectonophysics 631, 176-188, http://dx.doi.org/110.1016/j.tecto.2014.1004.1039.

Photiades, A. D., 2002, The ophiolitic molasse unit of Ikaria island (Greece): Turkish J. Earth Sci., v. 11, p. 27-38.

Piromallo, C., Becker, T. W., Funiciello, F., and Faccenna, C., 2006, Three-dimensional instantaneous mantle flow induced by subduction: J. Geophys. Res., v. 33, no. L08304, doi:10.1029/2005GL025390.

Piromallo, C., and Morelli, A., 2003, P wave tomography of the mantle under the AlpineMediterranean area: J. Geophys. Res., v. 108, no. B2, p. 2065, doi: 2010.2129/2002JB001757.

Rabillard, A., Arbaret, L., Jolivet, L., Le Breton, N., Gumiaux, C., Augier, R., Grasemann, B., 2014. Interactions between plutonism and detachments during Metamorphic Core Complex formation, Serifos Island (Cyclades, Greece). Tectonics in press, DOI: 10.1002/2014TC003650.

Réhault, J. P., Honthaas, C., Guennoc, P., Bellon, H., Ruffet, G., Cotten, J., Sosson, M., and Maury, R. C., 2012, Offshore Oligo-Miocene volcanic fields within the CorsicaLiguria Basin: Magmatic diversity and slab evolution in the western Mediterranean Sea: Journal of Geodynamics, v. 58, p. 73-95, doi:10.1016/j.jog.2012.1002.1003.

Reilinger, R., McClusky, S., Paradissis, D., Ergintav, S., and Vernant, P., 2010, Geodetic constraints on the tectonic evolution of the Aegean region and strain accumulation along the Hellenic subduction zone: Tectonophysics, v. 488, p. 22-30.

Rice, H. N., Iglseder, C., Grasemann, B., Zamolyi, A., Nikolakopoulos, K. G., Mitropoulos, D., Voit, K., Müller, M., Draganits, E., Rockenschaub, M., and Tsombos, P. I., 2012, A new geological map of the crustal-scale detachment on Kea (Western Cyclades, Greece): Austrian Journal of Earth Sciences, v. 105, no. 3, p. 108-124.

Ring, U., Gessner, K., Güngör, T., and Passchier, C. W., 1999a, The Menderes massif of western Turkey and the Cycladic massif in the Aegean: do they really correlate ?: J. Geol. Soc. London, v. 156, p. 3-6.

Ring, U., Laws, S., Bernet, M., 1999. Structural analysis of a complex nappe sequence and late-orogenic basins from the Aegean island of Samos, Greece. J. Struct. Geol. 21, $1575-1601$.

Ring, U., Glodny, J., Will, T., and Thomson, S., 2010, The Hellenic Subduction System: High-Pressure Metamorphism, Exhumation, Normal Faulting, and Large-Scale Extension: Annu. Rev. Earth Planet. Sci., v. 38, p. 45-76, 10.1146/annurev.earth.050708.170910.

Ring, U., Glodny, J., Will, T. M., and Thomson, S., 2011, Normal faulting on Sifnos and the South Cycladic Detachment System, Aegean Sea, Greece: Journal of the Geological Society, London, v. 168, p. 751-768; doi: 710.1144/0016-76492010-76492064.

Ring, U., Laws, S., and Bernet, M., 1999b, Structural analysis of a complex nappe sequence and late-orogenic basins from the Aegean island of Samos, Greece: J. Struct. Geol., v. 21, p. 1575-1601.

Ring, U., Thomson, S. N., and Bröcker, M., 2003, Fast extension but little exhumation: the Vari detachment in the Cyclades, Greece: Geological Magazine, v. 140, no. 3, p. 245252. 
Rosenbaum, G., and Lister, G., 2004, Neogene and Quaternary rollback evolution of the Tyrrhenian Sea, the Apennines, and the Sicilian Maghrebides: Tectonics, v. 23, p. TC1013, doi:1010.1029/2003TC001518.

Ross, J. V., and Zimmerman, J., 1996, Comparison of evolution and tectonic significance of the Pindos and Vourinos ophiolite suites, northern Greece: Tectonophysics, v. 256, p. $1-15$.

Royden, L. H., and Papanikolaou, D. J., 2011, Slab segmentation and late Cenozoic disruption of the Hellenic arc: Geochem. Geophys. Geosyst, v. 12, no. 3, p. Q03010, doi:03010.01029/02010GC003280.

Salaün, G., Pedersen, H., Paul, A., Farra, V., Karabulut, H., Hatzfeld, D., Papazachos, C., Childs, D. M., Pequegnat, C., and the SIMBAAD Team, 2012, High resolution surface wave tomography beneath the Aegean-Anatolia region: constraints on upper mantle structure: Geophysical J. Int., v. 190, p. 406-420, doi: 410.1111/j.13651246X.2012.05483.x.

Sanchez-Gomez, M., Avigad, D., and Heiman, A., 2002, Geochronology of clasts in allochthonous Miocene sedimentary sequences on Mykonos and Paros islands: implications for back-arc extension in the Aegean Sea: J. Geol. Soc. London, v. 159, p. 45-60.

Schildgen, T.F., Yıldırım, C., Cosentino, D., Strecker, M.R., 2014. Linking slab break-off, Hellenic trench retreat, and uplift of the Central and Eastern Anatolian plateaus. EarthScience Reviews 128, 147-168, http://dx.doi.org/110.1016/j.earscirev.2013.1011.1006.

Schliestedt, M., Bartsch, V., Carl, M., Matthews, A., and Henjes-Kunst, F., 1994, The P-T path of greenschist-facies rocks from the island of Kithnos (Cyclades, Greece): Chemie der Erde, v. 54, p. 281-296.

Schneider, D. A., Senkowski, C., Vogel, H., Grasemann, B., Iglseder, C., and Schmitt, A. K., 2011, Eocene tectonometamorphism on Serifos (western Cyclades) deduced from zircon depth-profiling geochronology and mica thermochronology: Lithos, v. 125, p. 151-172, doi:110.1016/j.lithos.2011.1002.1005.

Seghedi, I., Ersoy, Y.E., Helvac1, C., 2013. Miocene-Quaternary volcanism and geodynamic evolution in the Pannonian Basin and the Menderes Massif: A comparative study. Lithos 180-181, 25-42, doi:10.1016/j.lithos.2013.1008.1017.

Sengör, A. M. C., and Yilmaz, Y., 1981, Tethyan evolution of Turkey: a plate tectonic approach: Tectonophysics, v. 75, p. 181-241.

Seward, D., Vanderhaeghe, O., Siebenaller, L., Thomson, S., Hibsch, C., Zingg, A., Holzner, P., Ring, U., and Duchêne, S., 2009, Cenozoic tectonic evolution of Naxos Island through a multi-faceted approach of fission-track analysis, in Ring, U., and Wernicke, B., eds., Extending a continent: architecture, rheology and heat budget, Volume 321: London, Geological Society, p. 179-196.

Skarpelis, N., Kyriakopoulos, K., and Villa, I., 1992, occurrence and 40Ar/39Ar dating of a granite in Thera (Santorini, Greece): Geologische Rundschau, v. 81, no. 3, p. 729-735.

Skarpelis, N., Tsikouras, B., and Pe-Piper, G., 2008, The Miocene igneous rocks in the Basal Unit of Lavrion (SE Attica, Greece): petrology and geodynamic implications: geol. Mag., v. 145, no. 1, p. 1-15, doi:10.1017/S0016756807003949.

Soukis, K., and Stockli, D., 2013, Structural and thermochronometric evidence for multi-stage exhumation of Southern Syros, Cycladic Islands, Greece: Tectonophysics, v. 595-596, p. 148-164, doi:110.1016/j.tecto.2012.1005.1017.

Spakman, W., and Wortel, R., 2004, A tomographic view on Western Mediterranean geodynamics, in Cavazza, W., Roure, F. M., Spakman, W., Stampfli, G. M., and 
Ziegler, P. A., eds., The TRANSMED Atlas - The Mediterranean region from crust to Mantle: Berlin, Heidelberg, Springer, p. 31-52.

St. Seymour, K., Zouzias, D., Tombros, S., and Kolaiti, E., 2009, Geochemistry of the Serifos pluton (Cycladic islands) and associated iron oxide and sulfide ores: Skarn or metamorphosed exhalite deposits?: Neues Jahrbuch für Mineralogie - Abhandlungen, v. 186 , no. 3 , p. $249-270$.

Sternai, P., Menant, A., Jolivet, L., and Gerya, T., 2014, Subduction and mantle flow driving surface deformation in the Aegean-Anatolian system: Earth Planet. Sci. lett. 405, 110-118; dx.doi.org/110.1016/j.epsl.2014.1008.1023.

Stouraiti, C., Mitropoulos, P., Tarney, J., Barreiro, B., McGrath, A. M., and Baltatzis, E., 2010, Geochemistry and petrogenesis of late Miocene granitoids, Cyclades, southern Aegean: Nature of source components: Lithos, v. 114, p. 337-352, doi:310.1016/j.lithos.2009.1009.1010.

Suckale, J., Rondenay, S., Sachpazi, M., Charalampakis, M., Hosa, A., and Royden, L. H., 2009, High-resolution seismic imaging of the western Hellenic subduction zone using teleseismic scattered waves: Geophys. J. Int., v. 178, p. 775-791. doi: 710.1111/j.1365-1246X.2009.04170.x.

Trotet, F., Jolivet, L., and Vidal, O., 2001a, Tectono-metamorphic evolution of Syros and Sifnos islands (Cyclades, Greece): Tectonophysics, v. 338, p. 179-206.

Trotet, F., Vidal, O., and Jolivet, L., 2001b, Exhumation of Syros and Sifnos metamorphic rocks (Cyclades, Greece). New constraints on the P-T paths: Eur. J. Mineral., v. 13, p. 901-920.

Tschegg, C., and Grasemann, B., 2009, Deformation and alteration of a granodiorite during low-angle normal faulting (Serifos, Greece): Lithosphere, v. 1, no. 3, p. 139-154; doi: 110.1130/L1133.1131.

Urai, J. L., Shuiling, R. D., and Jansen, J. B. H., 1990, Alpine deformation on Naxos (Greece), in Knipe, R. J., and Rutter, E. H., eds., Deformation mechanisms, Rheology and tectonics, Volume 54, Geol. Soc. spec. Pub., p. 509-522.

van der Meulen, M. J., Meulenkamp, J. E., and Wortel, M. J. R., 1998, Lateral shifts of Apenninic foredeep depocentres reflecting detachment of subducted lithosphere: Earth Planet. Sci. Lett., v. 154, p. 201-218.

van Hinsbergen, D. J. J., 2010, A key extensional metamorphic complex reviewed and restored: The Menderes Massif of western Turkey: Earth-Science Reviews, v. 102, p. 60-76.

van Hinsbergen, D. J. J., Hafkenscheid, E., Spakman, W., Meulenkamp, J. E., and Wortel, R., 2005a, Nappe stacking resulting from subduction of oceanic and continental lithosphere below Greece: Geology, v. 33, no. 4, p. 325-328, doi: 310.1130/G20878.20871;

van Hinsbergen, D. J. J., Langereis, C. G., and Meulenkamp, J. E., 2005b, Revision of the timing, magnitude and distribution of Neogene rotations in the western Aegean region: Tectonophysics, v. 396, no. 1-2, p. 1-34.

van Hinsbergen, D. J. J., and Schmid, S. M., 2012, Map view restoration of Aegean-West Anatolian accretion and extension since the Eocene: Tectonics, v. 31, p. TC5005, doi:5010.1029/2012TC003132.

Vandenberg, L. C., and Lister, G. S., 1996, Structural analysis of basement tectonics from the Aegean metamorphic core complex of Ios, Cyclades, Greece: J. Struct. Geol, v. 18, no. 12 , p. $1437-1454$.

Vanderhaeghe, O., 2004, Structural development of the Naxos migmatite dome, in Whitney, D. L., Teyssier, C., and Siddoway, C. S., eds., Gneiss domes in orogeny, Volume 380: Boulder, Colorado, Geological Society of America, p. 211-227. 
Vassilakis, A., Royden, L., and Papanikolaou, D., 2011, Kinematic links between subduction along the Hellenic trench and extension in the Gulf of Corinth, Greece: A multidisciplinary analysis: Earth Planet. Sci. lett., v. 303, p. 108-120, doi:110.1016/j.eps1.2010.1012.1054.

Walcott, C. R., and White, S. H., 1998, Constraints on the kinematics of post-orogenic extension imposed by stretching lineations in the Aegean region: Tectonophysics, v. 298, p. 155-175.

Wijbrans, J. R., and McDougall, I., 1988, Metamorphic evolution of the Attic Cycladic Metamorphic Belt on Naxos (Cyclades, Greece) utilizing ${ }^{40} \mathrm{Ar} /{ }^{39} \mathrm{Ar}$ age spectrum measurements: J. Metamorph. Geol., v. 6, p. 571-594.

Wortel, M.J.R., Spakman, W., 1992. Structure and dynamic of subducted lithosphere in the Mediterranean. Proc. Kon. Ned. Akad. v. Wetensch 95, 325-347.

Wortel, M. J. R., and Spakman, W., 2000, Subduction and slab detachment in the Mediterranean-Carpathian region: Science, v. 290, p. 1910-1917.

Yogodzinski, G. M., Lees, J. M., Churikova, T. G., Dorendorf, F., Wöerner, G., and Volynets, O. N., 2001, Geochemical evidence for the melting of subducting oceanic lithosphere at plate edges: Nature, v. 409, no. 6819, p. 500-504.

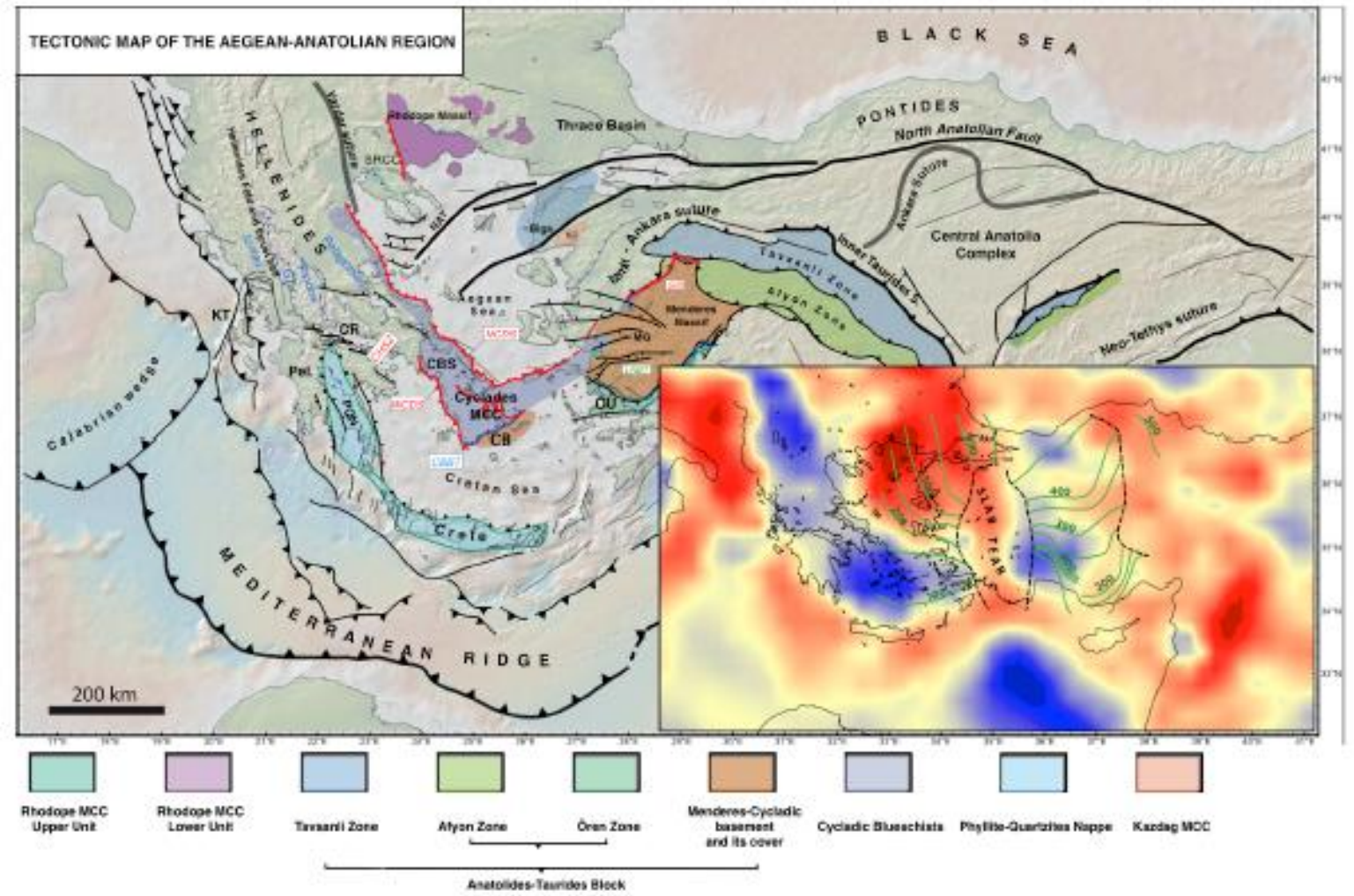

Figure 1: Geological and geodynamic context of exhumed metamorphic complexes in the Aegean Sea and Anatolia and (insert) P-wave seismic tomography model of the upper mantle (average between 100 and $250 \mathrm{~km}$ ) after Piromallo and Morelli (2003). The geometry of the slab tear is shown with the interpretation of the P-wave tomographic model of Berk Biryol et al (2011) and the isobaths of the slab shown in Gessner et al. (2013). 


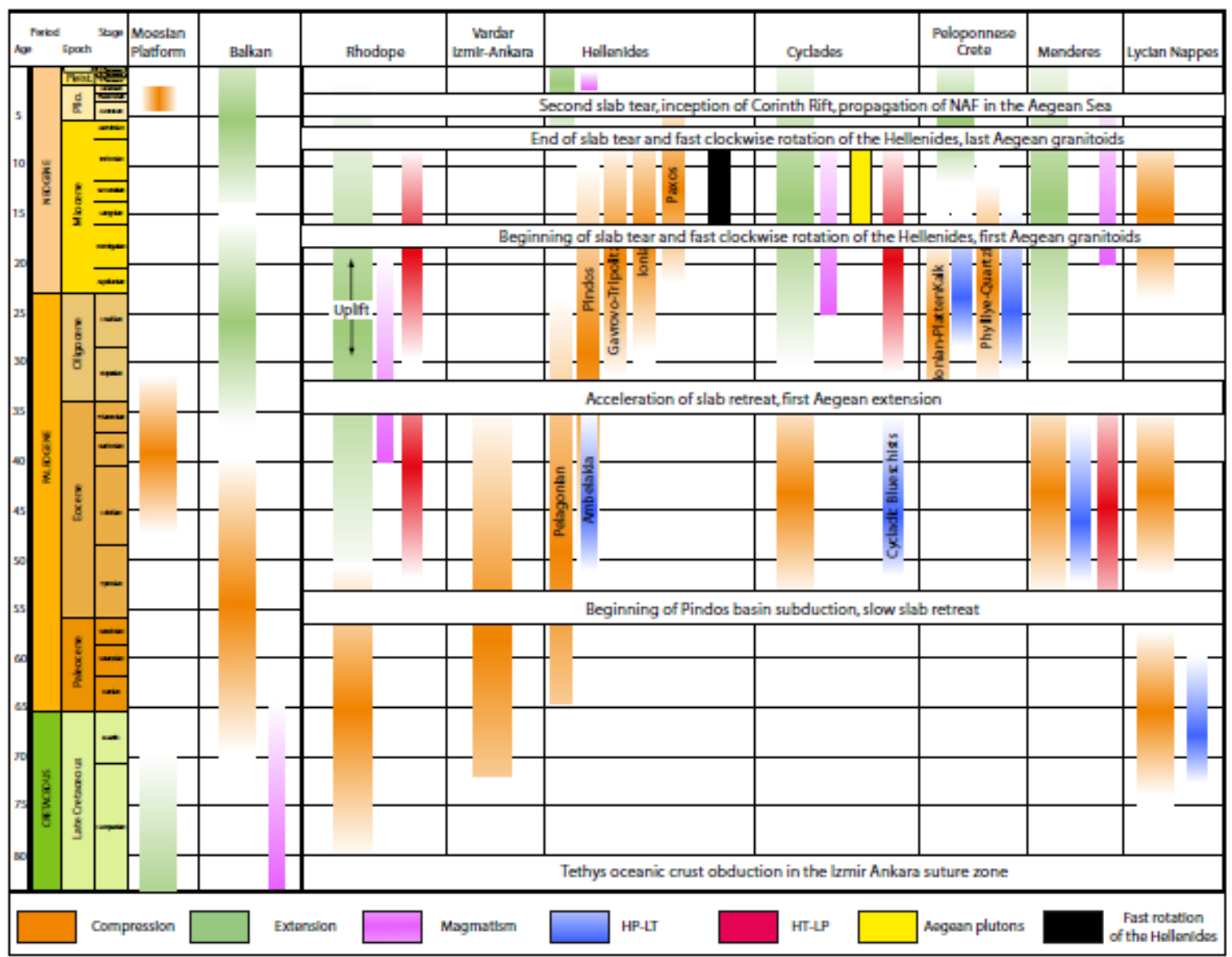

Figure 2: Synthesis of the main tectonic and magmatic events in the Aegean region (references in text and in Jolivet and Brun, 2010). 


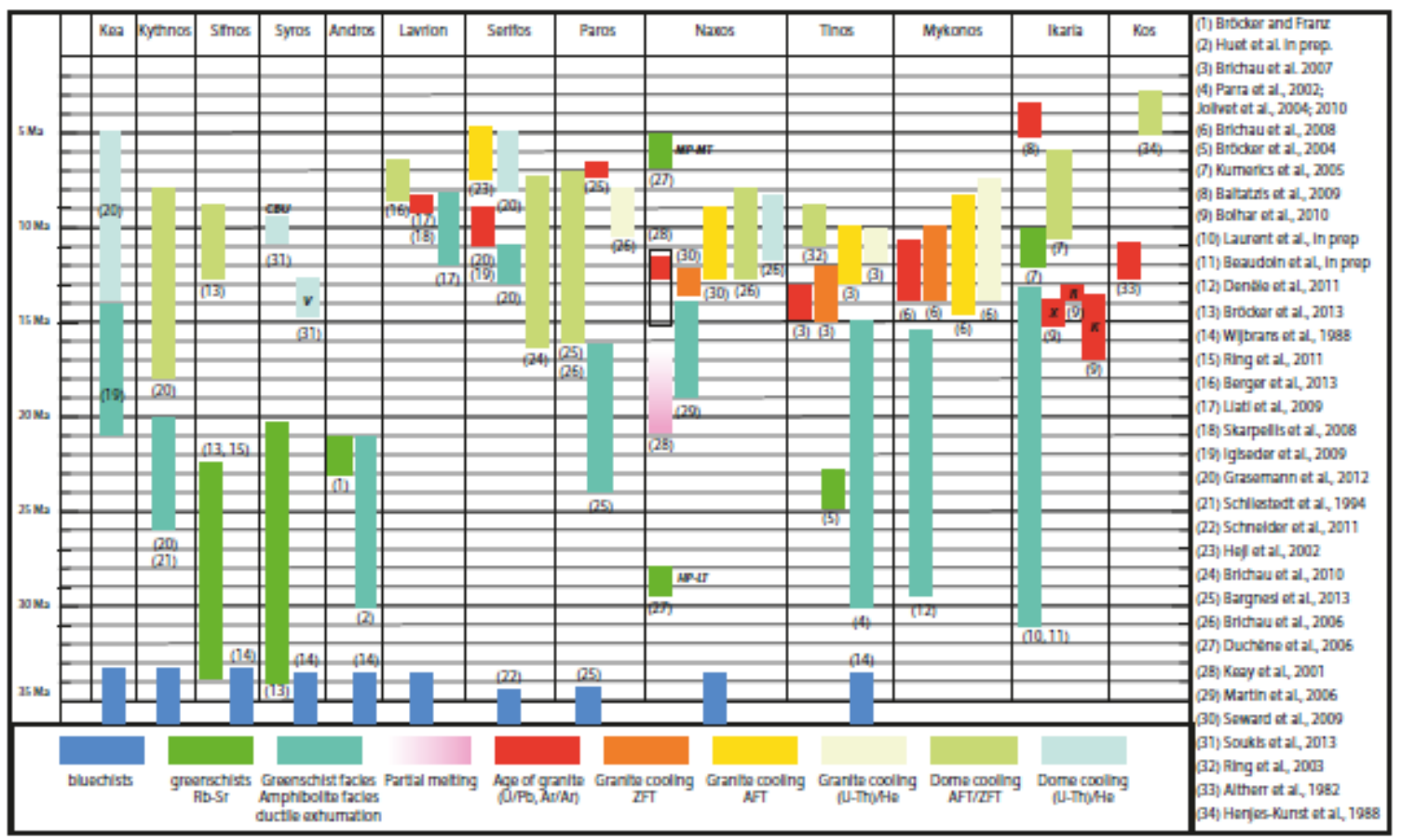

Figure 3: timing of metamorphic and exhumation events as well as the history of plutons from intrusion to final cooling in the Aegean region, from (Altherr et al., 1982; Henjes-Kunst et al., 1988; Wijbrans and McDougall, 1988; Schliestedt et al., 1994; Keay et al., 2001; Hejl et al., 2002; Parra et al., 2002; Ring et al., 2003; Bröcker et al., 2004; Jolivet et al., 2004a; Kumerics et al., 2005; Brichau et al., 2006; Bröcker and Franz, 2006; Duchêne et al., 2006; Martin et al., 2006; Brichau et al., 2007; 2008; Skarpelis et al., 2008; Baltatzis et al., 2009; Iglseder et al., 2009; Liati et al., 2009; Seward et al., 2009; Bolhar et al., 2010; Brichau et al., 2010; Jolivet et al., 2010; Denèle et al., 2011; Ring et al., 2011; Schneider et al., 2011; Grasemann et al., 2012; Bargnesi et al., 2013; Berger et al., 2013; Bröcker et al., 2013; Soukis and Stockli, 2013; Beaudoin et al., 2014; Huet et al., 2014; Laurent et al., 2015) 


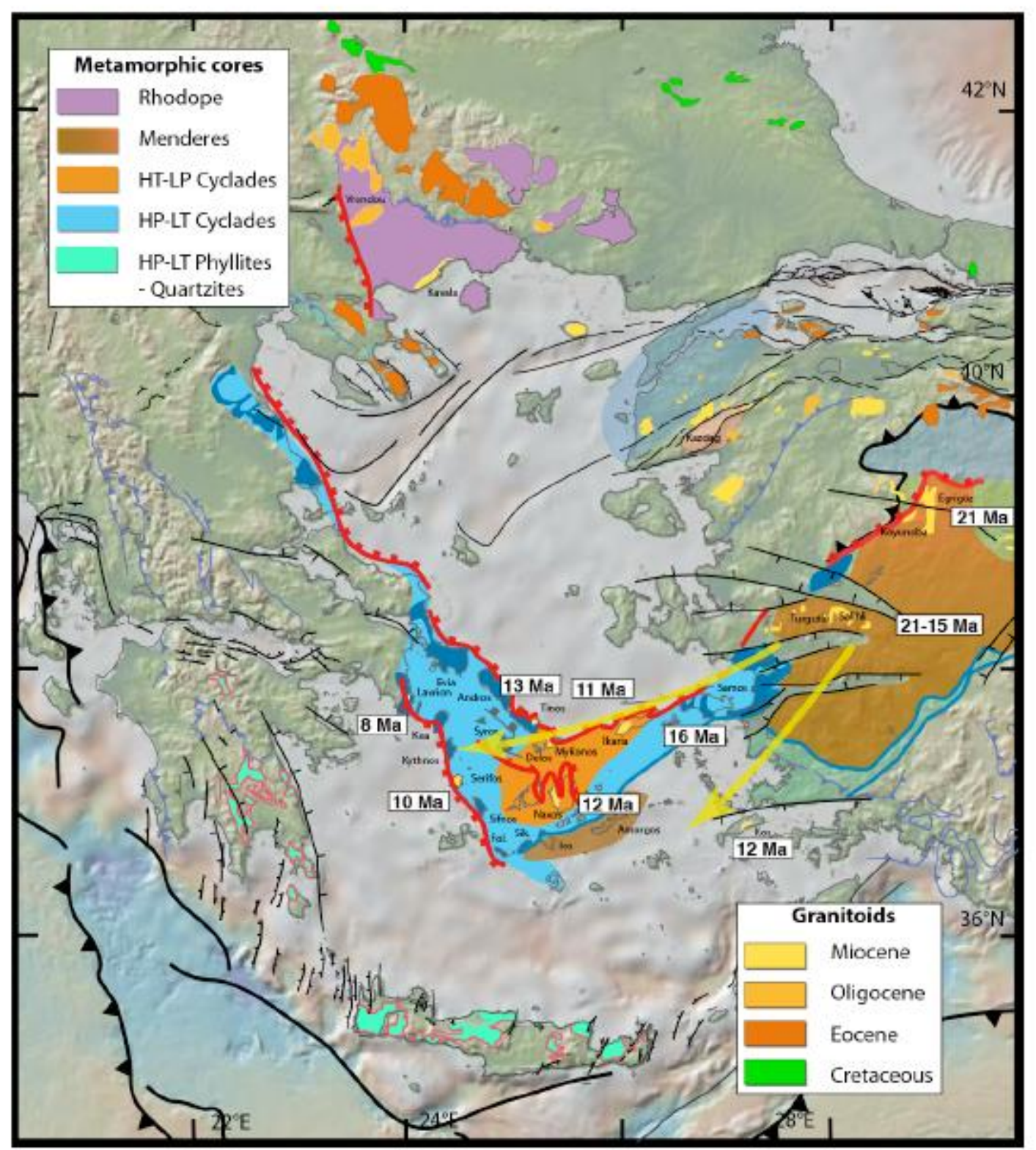

Figure 4: Granitoids in the Aegean region in their tectonic framework 


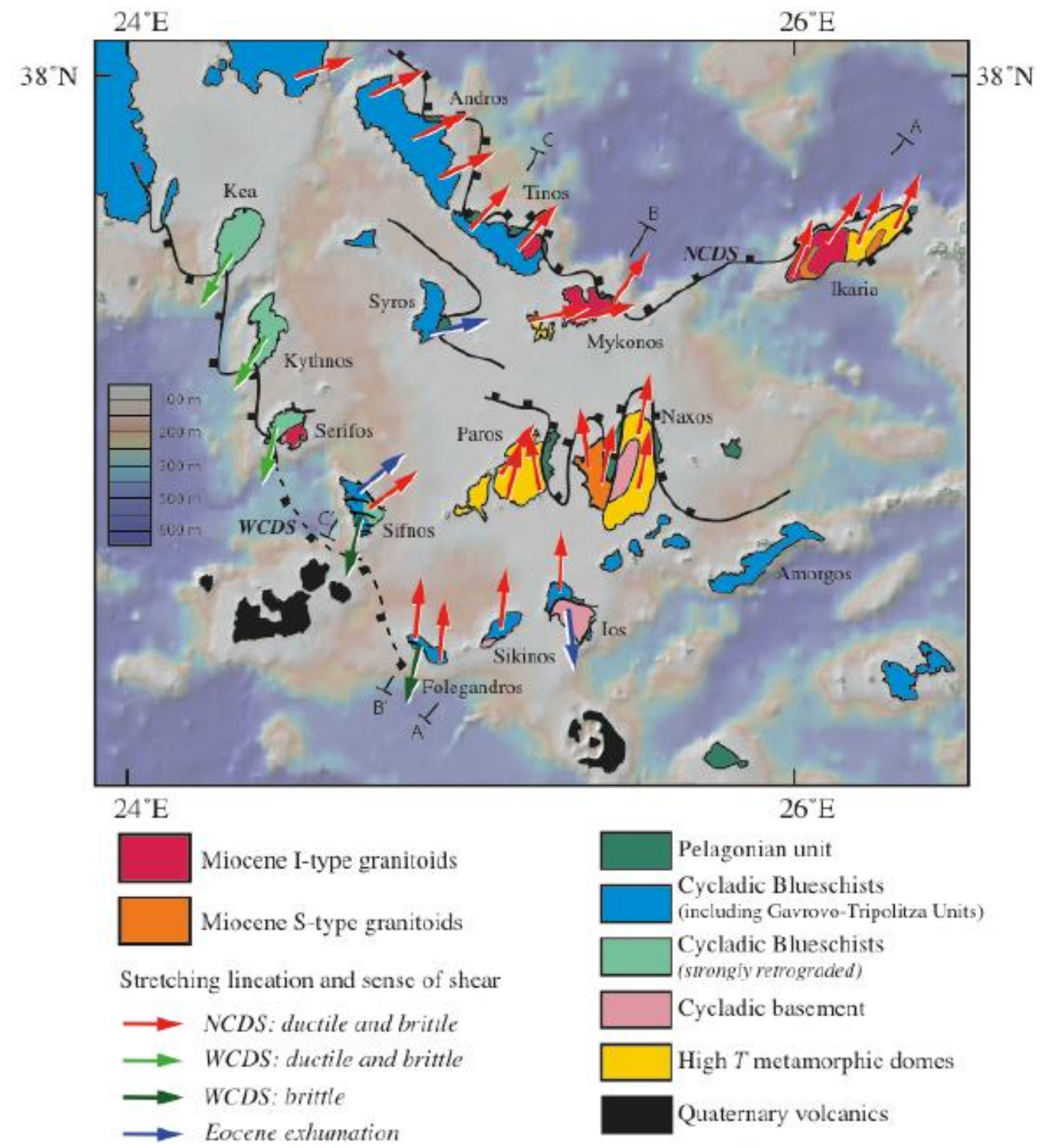

Figure 5: Tectonic map of the Cyclades archipelago showing the main metamorphic core complexes and plutons, as well as kinematic indicators. After Gautier and Brun (1994a, b), Huet et al. (2009); Jolivet et al., (2010; 2013), Grasemann et al. (2012), Augier et al. (submitted). NCDS: North Cycladic Detachment System. WCDS: West Cycladic Detachment System. 


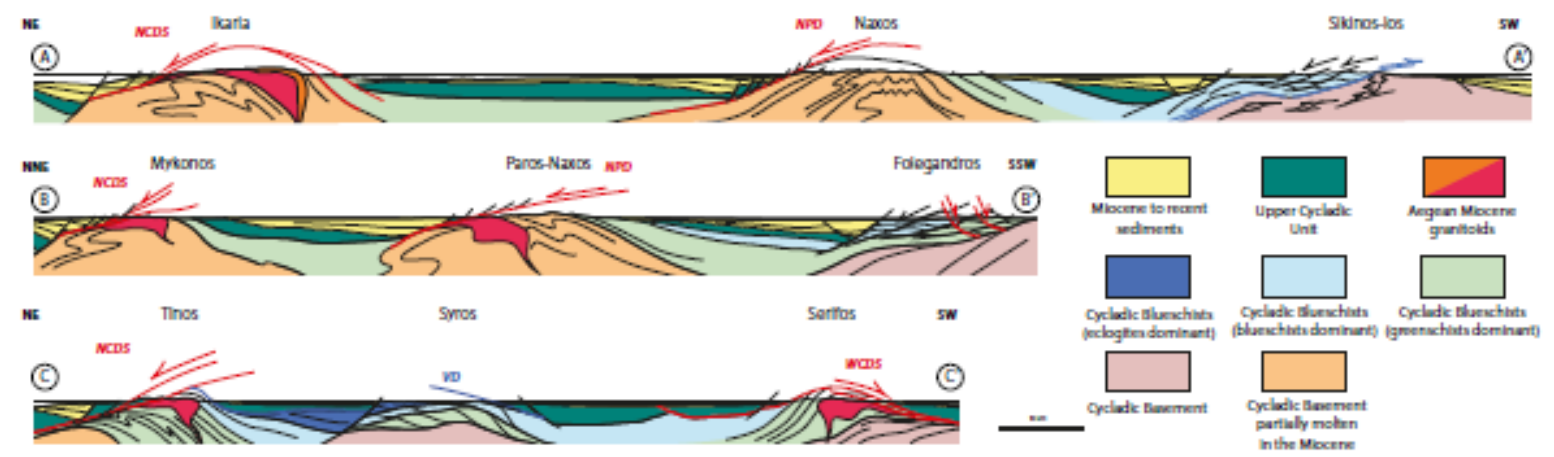

Figure 6: Three sections through the Cyclades metamorphic core complexes. 


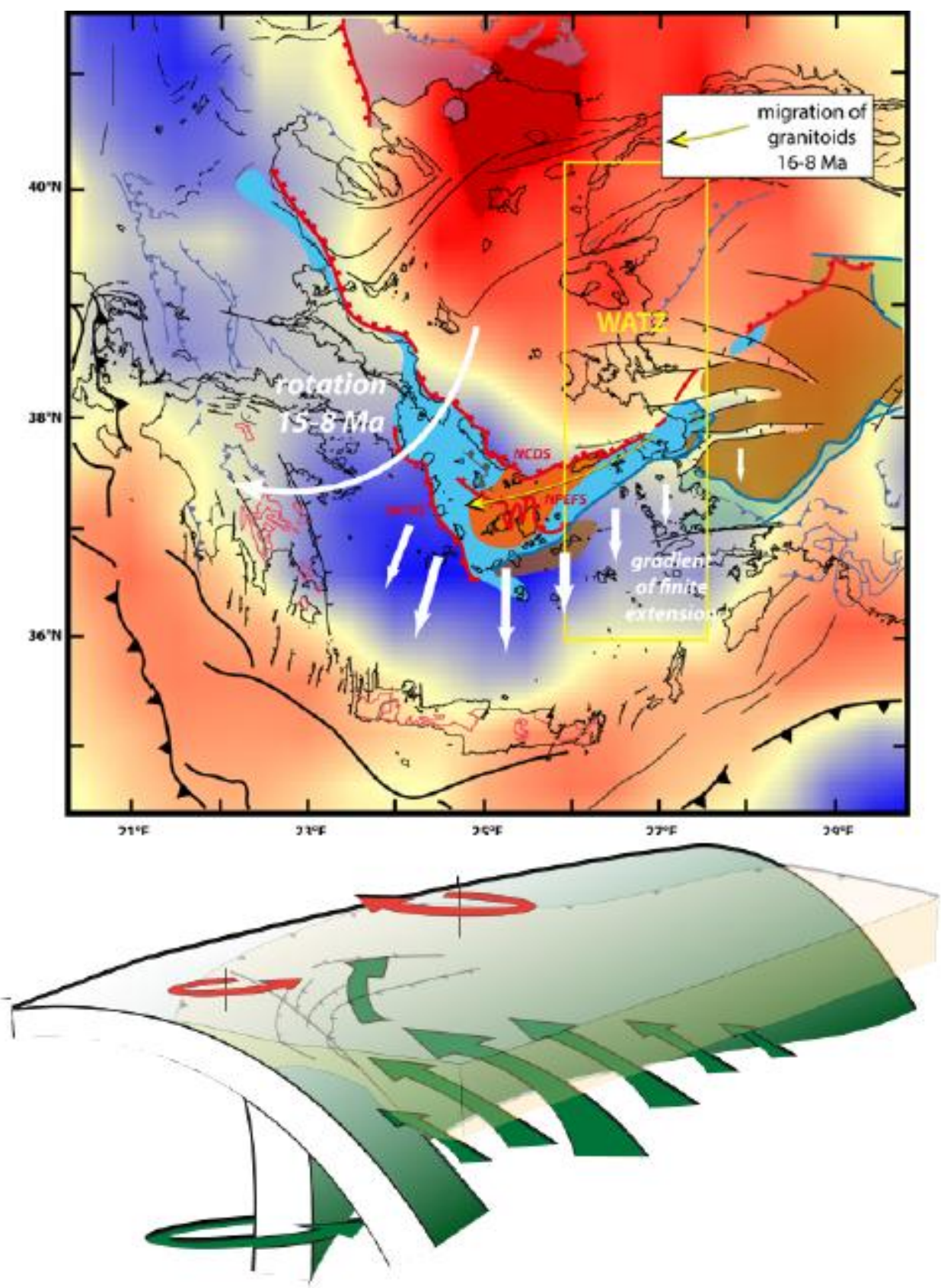

Figure 7: Schematic interpretation of the coeval fast rotation of the Hellenides (van Hinsbergen et al., 2005) and fast migration of granitoids in the Aegean realm between 16 and $8 \mathrm{Ma}$. The rotation is accommodated by a wide gradient of extension and southward mantle flow encompassing the domain where high-temperature metamorphic domes crop out. See also Ring et al. (1999b) for an earlier suggestion of the existence of a left-lateral transfer zone in the eastern Aegean. This gradient is similar to the West Anatolia Transfer Zone (WATZ) proposed by Gessner et al. (2013). NCDS: North Cycladic Detachment System, WCDS: West Cycladic Detachment System, NPEFS: Naxos-Paros Extensional fault System. 


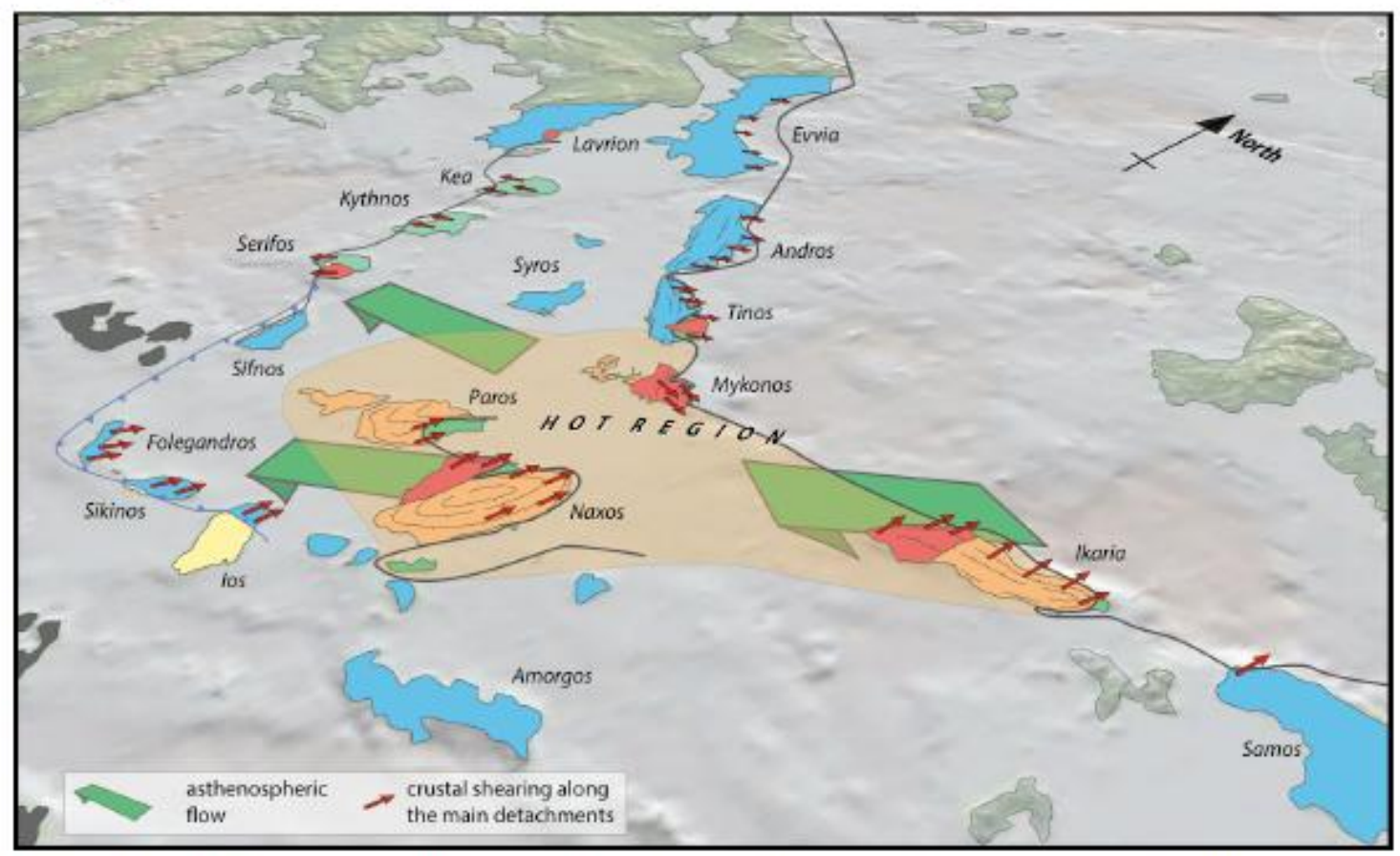

Figure 8: Oblique view on the Cyclades showing the main elements discussed in the text and the relations between mantle flow and exhumation of metamorphic core complexes (MCC) between 17 and $8 \mathrm{Ma}$. Ikaria, Naxos, Paros and Mykonos MCC's are exhumed above a hot region where hot asthenospheric flow is triggered by the slab tear.

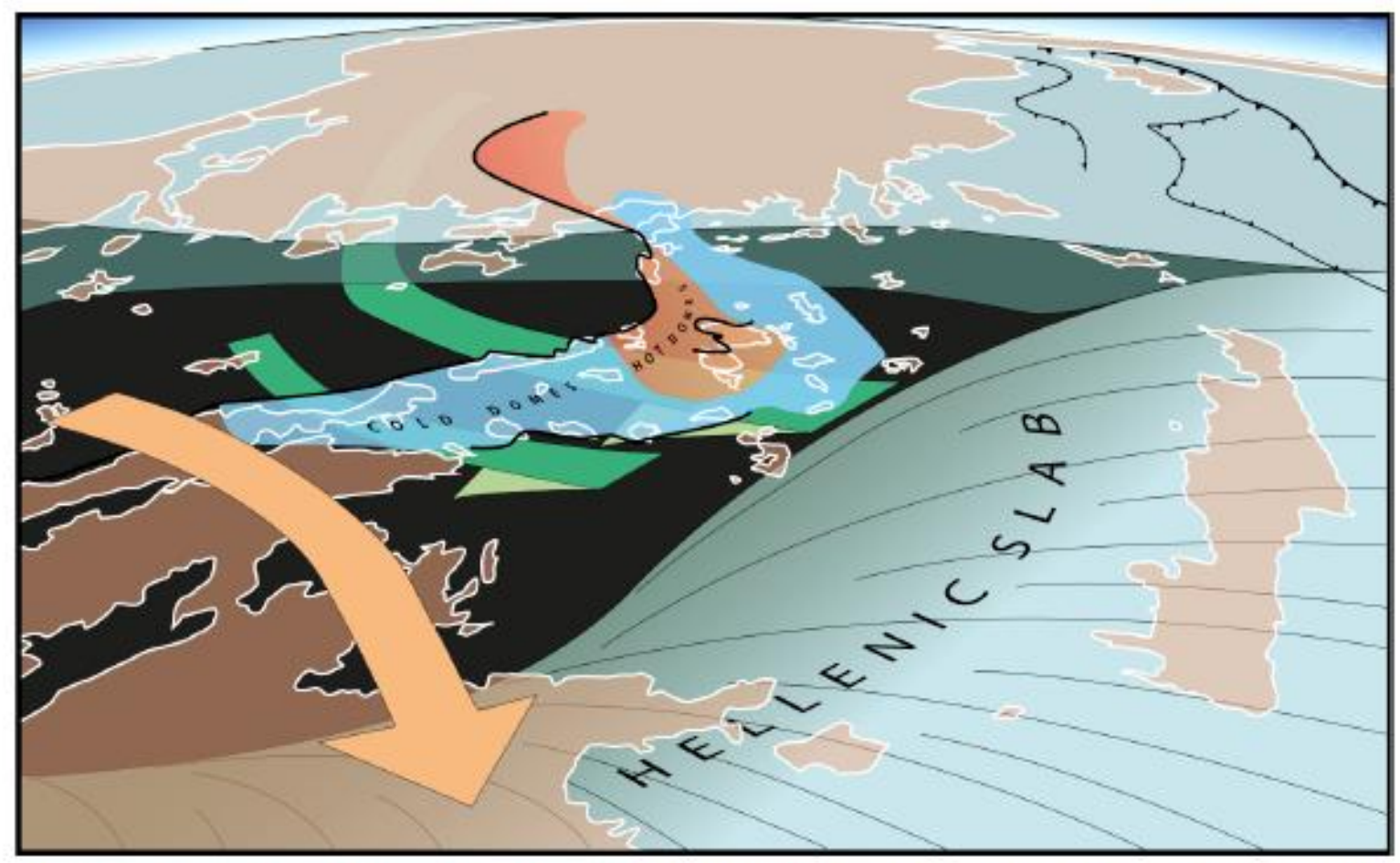

Figure 9: An oblique view of the relations between slab tear, rotations and mantle flow below the Aegean between 17 and $8 \mathrm{Ma}$. 


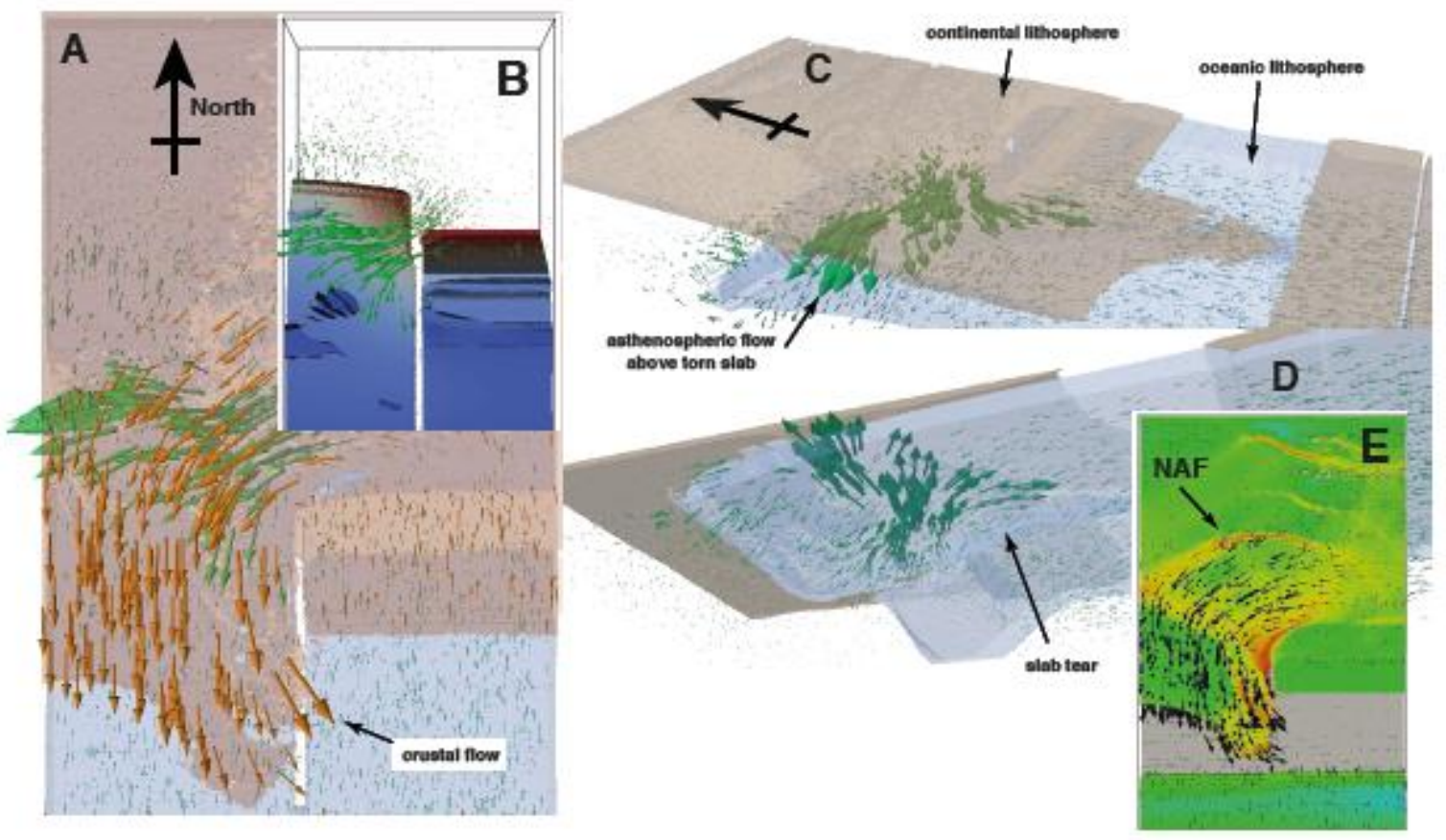

Figure 10: Map view and two oblique views of the numerical model of Sternai et al., (2014). Blue domain represents the mantle of the subducting plate and the brown domain continental crust. Brown arrows show the crustal flow at the surface while green arroms show the flow in the mantle. The $N-S$ white line in map view shows the prescribed weak zone in the subducting lithosphere. A: Map view of the surface of the model with the crustal and asthenospheric displacement vectors. B: View from above of the $3 \mathrm{~d}$ model showing the flow in the asthenospheric mantle and the slab colored with depth (blue to red). C: Oblique $3 D$ view from above. $D$ : Oblique $3 D$ view from below. E: Map view showing the crustal displacement vectors (black arrows and the strain rate) from Sternai et al. (2014). 